\title{
Effect of calcium salts of a mixture of conjugated linoleic acids containing trans-10, cis-12 in the diet on milk fat synthesis in goats
}

\author{
Kevin J. Shingfield ${ }^{1}$, Jacques Rouel $^{2}$ and Yves Chilliard ${ }^{2} *$ \\ ${ }^{1}$ Animal Production Research, MTT Agrifood Research Finland, FIN-31600, Jokioinen, Finland \\ ${ }^{2}$ UR1213 Herbivores, Institut National de la Recherche Agronomique (INRA), Site de Theix, F-63122, St-Genès-Champanelle, France
}

(Received 7 April 2008 - Revised 15 July 2008 - Accepted 24 July 2008 - First published online 25 September 2008)

Dietary supplements of conjugated linoleic acid (CLA) containing trans-10, cis-12 CLA decrease milk fat secretion in the lactating cow and sheep, but their effects on mammary lipogenesis in the goat are less well defined. Eight lactating goats were used in two $4 \times 4$ Latin-square experiments with $14 \mathrm{~d}$ experimental periods to examine the effects of calcium salts of CLA methyl esters (CaCLA) containing trans-10, cis-12 on milk fat synthesis. Experimental treatments consisted of incremental inclusion of $0,30,60$ or $90 \mathrm{~g}$ of CaCLA/d (corresponding to 7.47, 14.9 and $22.4 \mathrm{~g} / \mathrm{d}$ of trans-10, cis-12 CLA) offered during the first $10 \mathrm{~d}$ of each experimental period that replaced maize grain in concentrates (Experiment 1) or calcium salts of palm oil fatty acids (Experiment 2). Relative to the control, inclusion of 30, $60 \mathrm{or} 90 \mathrm{~g}$ CaCLA/d in the diet reduced milk fat yield by $19.8,27.9$ and $32.3 \%$ and $17.5,39.0$ and $49.3 \%$ in Experiments 1 and 2, respectively. Decreases in milk fat were due to reductions in the secretion of fatty acids synthesised de novo rather than the uptake of fatty acids from the peripheral circulation. Indirect comparisons with the studies in the lactating cow indicated a lower efficacy of CaCLA supplements on mammary lipogenesis in the goat. In conclusion, CaCLA in the diet inhibits milk fat synthesis in the goat, responses that are dependent on the supply of dietary fatty acids, with evidence that the caprine is less sensitive to the anti-lipogenic effects of trans-10, cis-12 CLA compared with the bovine or ovine.

Conjugated linoleic acid: Milk fat synthesis: Goats: Lactation

It is well established that trans-10, cis-12 conjugated linoleic acid (CLA) is involved in the regulation of lipid metabolism in a number of mammalian species including the pig, cow and human ${ }^{(1)}$. Numerous studies have characterised the antilipogenic effects of trans-10, cis-12 CLA on milk fat synthesis in the lactating cow. In the bovine, reductions in milk fat are known to occur in a predictable and dose-dependent manner in response to post-ruminal infusions ${ }^{(2-4)}$ or rumen-protected

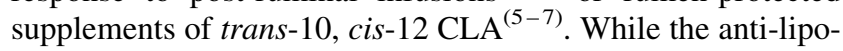
genic effects are well characterised in the lactating cow, the role of trans-10, cis-12 CLA in lipogenesis in other lactating ruminant species is less well defined.

The effects of stage of lactation on milk fat are known to be comparable in the bovine and caprine, but changes in milk fat synthesis to lipid supplements in the diet differ markedly between these species ${ }^{(8,9)}$. Typically, milk fat content is increased in response to dietary fat in the goat, but not in the cow, which may reflect inter-species differences in ruminal lipid metabolism and/or the regulation of cellular processes in the mammary gland and the relative importance of key enzymes in the synthesis of milk fatty acids ${ }^{(8,9)}$. Recent studies examining short-term intravenous ${ }^{(10)}$ or post-

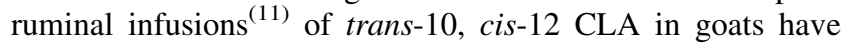
reported relatively minor or no effects on mammary lipogenesis. However, rumen-protected supplements of trans-10, cis-12 CLA were reported to decrease milk fat synthesis in goats $^{(12,13)}$, but the quantity required to inhibit milk fat synthesis in the goat was much higher than expected based on metabolic live-weight comparisons with the lactating cow. While inconclusive, the available evidence points towards a lower sensitivity to the anti-lipogenic effects of trans-10, cis-12 CLA in the caprine than in the bovine.

Further studies have demonstrated that the anti-lipogenic effects of trans-10, cis-12 CLA on milk fat synthesis in the lactating cow are markedly reduced when diets contain relatively high amounts of rumen-protected unsaturated fatty acids $^{(14)}$. Inter-species differences in milk fat responses to lipid supplements ${ }^{(8,9)}$ also suggest that the supply of fatty acid precursors available to the mammary gland would have a more critical role on the inhibitory effects of trans-10, cis-12 CLA on milk fat synthesis in the goat compared with the cow.

Eight lactating alpine goats were used in two $4 \times 4$ Latinsquare experiments to examine milk fat responses to incremental inclusion of calcium salts of a mixture of CLA isomers (CaCLA) containing trans-10, cis-12 in the diet. In order to establish the possible role of long-chain fatty acid precursor supply, CaCLA replaced maize grain in concentrate supplements (Experiment 1) or calcium salts of palm oil fatty acids (Experiment 2) in the diet. For both experiments, milk composition responses to the same range in trans-10, cis-12 CLA intakes were evaluated. CaCLA were selected as a source of rumen-protected trans-10, cis-12 CLA since the

Abbreviations: CaCLA, calcium salts of CLA methyl esters; CLA, conjugated linoleic acid; FAME, fatty acid methyl esters; CaPO, salts of palm oil fatty acid. * Corresponding author: Yves Chilliard, fax +33 473624519, email chilliar@clermont.inra.fr 
effects of these lipid supplements on milk fat synthesis have been determined in short-term experiments ${ }^{(5,15)}$ and extensively evaluated over an extended period during early $(6,7,16)$ and established lactation in the cow ${ }^{(17,18)}$, allowing an indirect comparison of the anti-lipogenic effects of trans-10, cis-12 CLA between ruminant species.

\section{Materials and methods}

Animal management and experimental design

All experimental procedures were approved by the Institut National de la Recherche Agronomique Animal Care and Use Committee in accordance with the guidelines on the use of animals for experimental purposes implemented in France $^{(19)}$. Eight lactating non-pregnant alpine goats in midlactation of mean 250 (SE 8.3) d in lactation, 63.9 (SE 4.33) $\mathrm{kg}$ live weight and producing 2.58 (SE $0 \cdot 121) \mathrm{kg}$ milk/d were used in two experiments each conducted as a $4 \times 4$ Latin square with $14 \mathrm{~d}$ experimental periods. Animals were assigned to Latin squares according to milk yield and milk composition determined over a $4 \mathrm{~d}$ period immediately before the start of the experiment. Mean milk yield $(\mathrm{kg} / \mathrm{d})$, milk fat, protein and lactose content $(\mathrm{g} / \mathrm{kg})$ were 2.59 (SE 0.085), 42.0 (SE 1.30), 39.6 (SE 1.20) and 43.9 (SE 1.65), and 2.58 (SE 0.235), 39.6 (SE 1.35), 36.7 (SE 0.40) and 42.9 (SE 1.05) for the goats used in Experiments 1 and 2, respectively. Experimental animals were housed in individual stalls and had continuous access to water. Daily rations were fed equal meals at 08.30 and 16.00 hours and goats were milked at 06.00 and 15.30 hours.

Experimental treatments consisted of CaCLA prepared from chemical isomerisation of sunflower-seed oil and containing cis-9, trans-11 CLA and trans-10, cis-12 CLA as major components (Im'prouve ALC, Xeris S.A., Séné, France; Table 1), and included in the diet at a rate of $0,30,60$ or $90 \mathrm{~g} / \mathrm{d}$ corresponding to $7.47,14.9$ and $22.4 \mathrm{~g}$ of trans-10, cis-12 CLA/d. Supplements of CaCLA were fed for the first $10 \mathrm{~d}$ of each experimental period but removed from daily rations during the remaining $4 \mathrm{~d}$ in order to minimise treatment carry-over effects. In Experiment 1, CaCLA replaced maize grain in concentrate supplements (treatments $\mathrm{C} 0, \mathrm{C} 1, \mathrm{C} 2$ and $\mathrm{C} 3$, respectively), while in Experiment 2 CaCLA substituted for calcium salts of palm oil fatty acids (CaPO) (treatments $\mathrm{CP} 0, \mathrm{CP} 1, \mathrm{CP} 2$ and CP3; Ruminer, Aurillac, France; Table 1, respectively). Replacing maize grain with CaCLA supplements also enhanced diet energy content in Experiment 1, whereas treatments $\mathrm{CP} 0, \mathrm{CP} 1, \mathrm{CP} 2$ and $\mathrm{CP} 3$ in Experiment 2 were formulated to be isoenergetic.

\section{Experimental diets}

Goats were offered lucerne hay ad libitum supplemented with $0.65 \mathrm{~kg} \mathrm{DM} / \mathrm{d}$ concentrates of variable composition (Table 2). Diets were formulated to supply 110 and $130 \%$ of predicted energy and protein requirements, respectively ${ }^{(20)}$. In Experiment 1 , CaCLA replaced (on a DM basis) maize grain in concentrate supplements or substituted for calcium salts of palm oil fatty acids in Experiment 2 (Table 2). For both experiments, concentrate supplements were fed at a fixed rate to avoid possible selection of dietary components, maintain the forage:concentrate ratio of the diet and ensure that
Table 1. Fatty acid composition of lipid supplements

\begin{tabular}{|c|c|c|}
\hline \multirow[b]{2}{*}{ Fatty acid composition (g/100 g fatty acids) } & \multicolumn{2}{|c|}{ Supplement } \\
\hline & $\mathrm{CaPO}$ & CaCLA \\
\hline $10: 0$ & 0.05 & 0.00 \\
\hline $12: 0$ & 0.41 & 0.00 \\
\hline $14: 0$ & 1.62 & 0.19 \\
\hline $15: 0$ & 0.00 & 0.00 \\
\hline $16: 0$ & $50 \cdot 58$ & 8.72 \\
\hline cis-9-16: 1 & $0 \cdot 18$ & $0 \cdot 11$ \\
\hline $17: 0$ & $0 \cdot 10$ & 0.00 \\
\hline $18: 0$ & $3 \cdot 70$ & $3 \cdot 21$ \\
\hline cis-9-18: 1 & $33 \cdot 62$ & $12 \cdot 24$ \\
\hline cis-11-18: 1 & 0.00 & 0.88 \\
\hline $18: 2 n-6$ & 8.35 & 0.73 \\
\hline cis-9,cis-11 CLA & 0.00 & 1.08 \\
\hline cis-10,cis-12 CLA & 0.00 & 0.89 \\
\hline cis-9,trans-11 CLA & 0.00 & 33.33 \\
\hline cis-11, trans-13 CLA & 0.00 & 0.14 \\
\hline trans-7,cis-9 CLA & 0.00 & 0.07 \\
\hline trans-8,cis-10 CLA & 0.00 & 1.51 \\
\hline trans-10,cis-12 CLA & 0.00 & 31.08 \\
\hline trans-7,trans-9 CLA & 0.00 & 0.07 \\
\hline trans-8,trans-10 CLA & 0.00 & 0.31 \\
\hline trans-9,trans-11 CLA & 0.00 & 1.09 \\
\hline trans-10,trans-12 CLA & 0.00 & $1 \cdot 10$ \\
\hline trans-11,trans-13 CLA & 0.00 & 0.06 \\
\hline trans-12,trans-14 CLA & 0.00 & 0.01 \\
\hline$\Sigma$ CLA & 0.00 & $72 \cdot 03$ \\
\hline $18: 3 n-3$ & 0.24 & 0.00 \\
\hline $20: 0$ & 0.19 & 0.00 \\
\hline $22: 0$ & 0.00 & 0.30 \\
\hline Unidentified & 1.00 & 0.46 \\
\hline$\Sigma$ Fatty acids (g/kg DM) & 884 & 770 \\
\hline
\end{tabular}

CaPO, calcium salts of palm oil fatty acids; CaCLA, calcium salts of conjugated linoleic acid.

experimental treatments supplied the targeted amount of trans-10, cis-12 CLA.

\section{Experimental measurements and sampling}

Foods

Individual intakes were recorded daily but only measurements made on days 9 and 10 of each experimental period were used for statistical analysis. During this interval, samples of lucerne hay, concentrate mixtures $\mathrm{C}, \mathrm{CP}, \mathrm{CP} 1$ and $\mathrm{CP} 2$, calcium salts of palm oil fatty acids and CaCLA supplements were collected, composited and stored at $-20^{\circ} \mathrm{C}$. Feed DM content was determined after drying at $105^{\circ} \mathrm{C}$ for $24 \mathrm{~h}$. Samples of maize silage, lucerne hay and concentrates were dried at $48^{\circ} \mathrm{C}$ for $48 \mathrm{~h}$, passed through a $1 \mathrm{~mm}$ screen and submitted for the determination of chemical composition according to standard procedures ${ }^{(21)}$. Additional samples of experimental feeds were collected, lyophilised (Thermovac TM-20, Froilabo, Ozoir-la-Ferrière, France) and submitted for fatty acid determinations.

\section{Milk}

Milk yields were recorded daily, but only measurements on days 9 and 10 of each experimental period were analysed statistically. Samples of milk were collected from individual goats over four consecutive milkings starting 06.00 hours on day 9 
Table 2. Ingredient and chemical composition of experimental hay and concentrate supplements

\begin{tabular}{|c|c|c|c|c|c|c|}
\hline & \multirow[b]{2}{*}{ Hay } & \multicolumn{5}{|c|}{ Concentrate $^{*}$} \\
\hline & & C & CPO & CP1 & CP2 & CP3 \\
\hline \multicolumn{7}{|l|}{ Ingredient (g/kg DM)† } \\
\hline Maize grain & & 561 & 468 & 487 & 520 & 561 \\
\hline Maize silage & & 135 & 124 & 130 & 134 & 135 \\
\hline Dehydrated sugarbeet pulp & & 143 & 131 & 137 & 141 & 143 \\
\hline Soyabean meal & & 144 & 132 & 138 & 142 & 144 \\
\hline CaPO $\ddagger$ & & 0 & 130 & 91 & 47 & 0 \\
\hline Minerals and vitamins $\S$ & & 16 & 15 & 16 & 16 & 16 \\
\hline \multicolumn{7}{|l|}{ Composition\| } \\
\hline $\mathrm{DM}(\mathrm{g} / \mathrm{kg})$ & 837 & 790 & 810 & 802 & 796 & 790 \\
\hline $\mathrm{OM}$ & 903 & 949 & 938 & 941 & 945 & 949 \\
\hline $\mathrm{CP}$ & 177 & 145 & 129 & 135 & 140 & 145 \\
\hline NDF & 567 & 219 & 195 & 204 & 212 & 219 \\
\hline ADF & 389 & 120 & 108 & 113 & 117 & 120 \\
\hline Starch & 0 & 422 & 355 & 370 & 393 & 422 \\
\hline $12: 0$ & 0.09 & 0.01 & 0.47 & 0.33 & 0.18 & 0.01 \\
\hline $14: 0$ & 0.14 & 0.03 & 1.84 & 1.30 & 0.68 & 0.03 \\
\hline $16: 0$ & $2 \cdot 37$ & 3.77 & $60 \cdot 2$ & $43 \cdot 3$ & $24 \cdot 0$ & 3.77 \\
\hline cis-9-16: 1 & 0.02 & 0.04 & 0.23 & $0 \cdot 17$ & 0.11 & 0.04 \\
\hline $18: 0$ & 0.33 & 0.51 & 4.60 & $3 \cdot 38$ & 1.97 & 0.51 \\
\hline cis-9-18: 1 & $0 \cdot 17$ & $6 \cdot 20$ & $43 \cdot 1$ & $32 \cdot 1$ & $19 \cdot 4$ & $6 \cdot 20$ \\
\hline cis-11-18: 1 & 0.03 & 0.18 & 0.15 & 0.16 & 0.17 & 0.18 \\
\hline $18: 2 n-6$ & 1.25 & 11.9 & $19 \cdot 6$ & $17 \cdot 2$ & $14 \cdot 6$ & 11.91 \\
\hline $18: 3 n-3$ & 1.82 & 0.74 & 0.93 & 0.88 & 0.81 & 0.74 \\
\hline $20: 0$ & 0.07 & 0.08 & 0.28 & 0.22 & 0.15 & 0.08 \\
\hline $22: 0$ & 0.08 & 0.04 & 0.04 & 0.04 & 0.04 & 0.05 \\
\hline $24: 0$ & 0.11 & 0.06 & 0.06 & 0.06 & 0.06 & 0.06 \\
\hline Other fatty acids & 0.84 & 0.50 & 1.72 & 1.35 & 0.94 & 0.50 \\
\hline$\Sigma$ Fatty acids & $7 \cdot 30$ & $24 \cdot 1$ & 133 & 100 & $63 \cdot 1$ & $24 \cdot 1$ \\
\hline \multicolumn{7}{|c|}{ 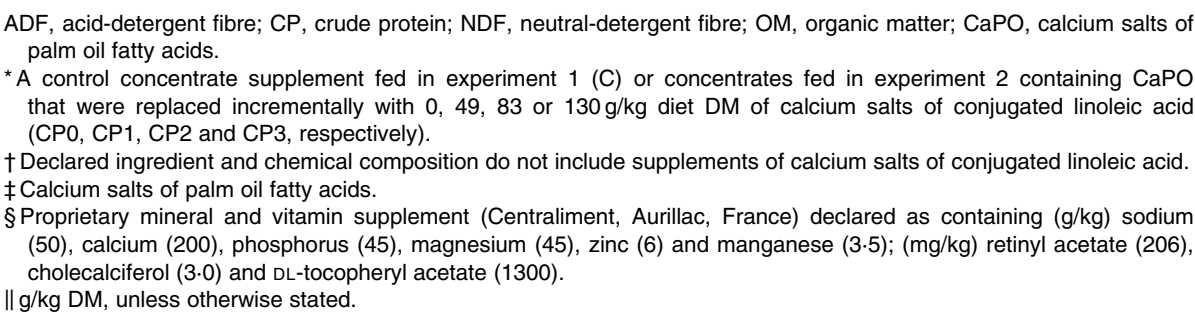 } \\
\hline
\end{tabular}

of each experimental period, preserved with potassium dichromate (Merck, Fontenay-Sous-Bois, France) and stored at $4^{\circ} \mathrm{C}$ until analysed for fat, crude protein and lactose content. Milk fat, crude protein and lactose were determined by near IR spectroscopy ${ }^{(21)}$ calibrated using reference caprine milk samples. Unpreserved milk samples were also collected at 15.30 hours on day 9 and 06.00 hours on day 10 , stored at $-20{ }^{\circ} \mathrm{C}$, composited according to yield and submitted for fatty acid analysis.

\section{Live weight}

Goats were weighed at the beginning of the experiment and on the last day of each experimental period at 11.00 hours.

\section{Fatty acid analysis}

Lipid in lucerne hay, concentrate ingredients and CaCLA supplements was extracted ${ }^{(22)}$ and transesterified to fatty acid methyl esters (FAME) by incubation with methanolic hydrochloric acid according to standard procedures ${ }^{(23)}$ using 23:0 (Sigma, St-Quentin Fallavier, France) as an internal standard. Lipid content and fatty acid composition of $\mathrm{CaPO}$ supplements were determined using the same extraction procedure $^{(22)}$, with the exception that the filtration step was omitted according to the recommendations of the manufacturer and the organic extract was transesterified to FAME using methanolic hydrochloric acid as a catalyst ${ }^{(23)}$.

For milk fatty acid determinations, lipid in $1 \mathrm{ml}$ samples was extracted and transesterified to FAME using freshly prepared methanolic sodium methoxide ${ }^{(24,25)}$. Methyl esters were quantified by GLC using a gas chromatograph Trace GC 2000 equipped with a flame ionisation detector (Thermo Finnigan, Les Ullis, France) and a fused silica capillary column $(100 \mathrm{~m} \times 0.25 \mathrm{~mm}$ internal diameter $)$ coated with $0.2 \mu \mathrm{m}$ film of cyanopropyl polysiloxane (CP-SIL 88; Chrompack 7489, Middelburg, The Netherlands) using hydrogen as the carrier gas operated at constant pressure $(125 \mathrm{kPa})$. Total FAME profile in a $2 \mu \mathrm{l}$ sample at a split ratio of 1:40 was determined using a temperature gradient programme ${ }^{(25)}$. Injector and detector temperatures were maintained at 255 and $260^{\circ} \mathrm{C}$, respectively. Peaks were routinely identified by comparison of retention times with FAME standards (GLC 463, Nu Chek Prep Inc., Elysian, MN, USA; reference mixture 47885 , Supelco, Bellefonte, PA, USA) and a reference butter oil (CRM 164; Commission of the European Communities, 
Community Bureau of Reference, Brussels, Belgium) was used to estimate correction factors for short-chain (4:010:0) fatty acids ${ }^{(26)}$. Methyl esters not contained in commercially available standards were identified based on the comparisons with reference milk fat samples of known fatty acid composition based on the GC-MS analysis of 4,4-dimethyloxazoline fatty acid derivatives ${ }^{(27,28)}$.

Following GLC analysis, samples of milk fat FAME were evaporated under nitrogen, dissolved in heptane and the distribution of CLA isomers was determined by HPLC using four silver-impregnated silica columns (ChromSpher 5 lipids, $250 \times 4.6 \mathrm{~mm}, 5 \mu \mathrm{m}$ particle size; Varian Ltd, Walton-onThames, UK) coupled in series and $0.1 \%(\mathrm{v} / \mathrm{v})$ acetonitrile in heptane as the mobile phase ${ }^{(29)}$. Isomers were identified using an authentic CLA methyl ester standard (O-5632; Sigma-Aldrich, YA-Kemia Limited, Helsinki, Finland) and chemically synthesised trans-9, cis-11 $\mathrm{CLA}^{(30)}$. Identification was verified by cross-referencing with the elution order reported in the literature ${ }^{(31)}$ using cis-9, trans-11 CLA as a landmark isomer.

\section{Statistical analysis}

Experimental data were subjected to ANOVA using the general linear model procedure of Statistical Analysis Systems software package version 9.1 (SAS Institute, Inc., Cary, NC, USA) with a model that included the random effects of the goat and fixed effects of period and treatment. Sums of squares for treatment effects were further separated using orthogonal contrasts into single-degree-of-freedom comparisons to test for the significance of linear, quadratic and cubic components of the response to experimental treatments. Least-squares means are reported and treatment effects were declared significant at $P<0.05$.

Relationships between CaCLA in the diet, milk fatty acid composition, fat content and milk fat secretion were initially examined by regression analysis using the REG procedure of SAS. In cases where close linear or quadratic associations were identified between experimental variables, the relationship was further explored with an exponential decay model fitted using the Marquardt non-linear algorithm within the NLIN procedure of $\mathrm{SAS}^{(32)}$.

\section{Results}

All animals remained in good health during the experiment, but in both experiments, goats did not consume all of the CaCLA supplement offered and therefore the amount of trans-10, cis-12 CLA supplied by experimental treatments was marginally lower than planned.

\section{Experiment 1}

Inclusion of CaCLA in the diet had no effect $(P>0.05)$ on DM intake, milk yield, milk protein content, milk lactose concentrations or live weight, but increased linearly $(P<0.01)$ fatty acid intake and decreased linearly $(P<0.01)$ milk fat content and yield (Table 3). Compared with the control, treatments $\mathrm{C} 1, \mathrm{C} 2$ and $\mathrm{C} 3$ resulted in $19.8,27.9$ and $32.3 \%$ decreases in milk fat yield and $16.2,22.7$ and $29.4 \%$ reductions in milk fat content, respectively. Reductions in milk fat synthesis to CaCLA were also accompanied by changes in milk fatty acid composition characterised by linear $(P<0.05)$ decreases in $6: 0,8: 0,10: 0,12: 0$, cis-18:1, 20:2n-6, 20:4n-6, 20:5n-3 and $22: 5 n-3$ and linear $(P<0 \cdot 05)$ increases in 18:0, $\Sigma$ trans18:1, $\Sigma$ CLA, 20:0, 22:0 and $\Sigma$ PUFA concentrations (Table 4). CaCLA supplements also induced linear or quadratic $(P<0.05)$ decreases in the concentration of fatty acids containing a cis-9 double bond, with the exception of cis-9, trans-13-18:2, and reduced product:substrate ratios for $\Delta$ 9-desaturase (Table 4). Concentrations of CLA isomers in milk other than trans-11, cis-13 were enhanced linearly $(P<0.05)$ in response to incremental inclusion of CaCLA in the diet (Table 5).

Incremental inclusion of CaCLA in the diet decreased linearly $(P<0.05)$ fatty acid secretion in milk due to reductions in both the output of $\leq \mathrm{C} 16$ fatty acids synthesised de novo and C16 fatty acids (Fig. 1 (a)). CaCLA supplements had no effect $(P>0.05)$ on the secretion of $>\mathrm{C} 18$ long-chain fatty acids in milk derived from the uptake of circulating plasma lipids (Fig. 1(a)). Experimental treatments increased linearly $(P<0.001)$ trans-10, cis-12 CLA output in milk from 14.7 to 163,296 and $404 \mathrm{mg} / \mathrm{d}$, associated with a mean efficiency of transfer from the diet into milk of $2.37,2.38$ and $2.19 \%$ (SE 0.099, $P=0.412$ ) for treatments $\mathrm{C} 1, \mathrm{C} 2$ and $\mathrm{C} 3$, respectively.

\section{Experiment 2}

Substituting CaCLA for $\mathrm{CaPO}$ in the diet had no effect $(P>0.05)$ on DM intake, milk yield, milk protein content, milk lactose concentrations or live weight, but decreased linearly $(P<0.01)$ milk fat content, milk fat output and fat-corrected milk yield (Table 6). Relative to the control, replacing $\mathrm{CaPO}$ with CaCLA in the diet resulted in 17.5 , 39.0 and $49.3 \%$ decreases in milk fat yield and $24.0,33.8$ and $35.8 \%$ reductions in milk fat content for treatments $\mathrm{CP} 1, \mathrm{CP} 2$ and $\mathrm{CP} 3$, respectively. Supplements $\mathrm{CaPO}$ and CaCLA were declared as containing the same amount of fatty acids. Due to measured differences in the supplement lipid content (Table 1), and marginal decreases in forage and concentrate DM intake, incremental replacement of $\mathrm{CaPO}$ with CaCLA in the diet resulted in a linear reduction $(P<0.05)$ in total fatty acid ingestion (Table 6). Replacing $\mathrm{CaPO}$ with CaCLA in the diet also altered milk fatty acid composition characterised by linear $(P<0.05)$ decreases in $6: 0,8: 0,10: 0,12: 0,16: 0$ and $20: 4 n-6$ and linear or quadratic $(P<0 \cdot 05)$ increases in 18:0, $\Sigma$ trans-18:1, $\Sigma$ CLA, 18:3n-3, 20:0, 20:2n-6, 22:0 and $\Sigma$ PUFA concentrations (Table 7). Substituting $\mathrm{CaPO}$ with CaCLA in the diet also induced linear or quadratic $(P<0 \cdot 05)$ decreases in the concentration of fatty acids containing a cis-9 double bond, other than cis9, trans-13-18:2 and reduced product:substrate ratios for $\Delta 9$ desaturase (Table 7). Incremental inclusion of CaCLA at the expense of $\mathrm{CaPO}$ also enhanced in a linear or quadratic manner $(P<0.05)$ the concentration of all CLA isomers in milk, with the exception of trans-11, cis-13 (Table 8).

Replacement of CaPO with CaCLA decreased linearly $(P<0.05)$ milk fatty acid output, changes that were attributable to a decrease in $\leq \mathrm{C} 14$ and $\mathrm{C} 16$ fatty acids, while the secretion of $>\mathrm{C} 18$ long-chain fatty acids in milk was independent of experimental treatment (Fig. 1(b)). Inclusion of 
Table 3. Effect of dietary conjugated linoleic acid (CLA) supplements on nutrient intake, milk production and live weight in lactating goats (Experiment 1$)^{\star}$

\begin{tabular}{|c|c|c|c|c|c|c|}
\hline & \multicolumn{4}{|c|}{ Treatment† } & \multirow[b]{2}{*}{ SEM $\ddagger$} & \multirow[b]{2}{*}{$P \S$} \\
\hline & $\mathrm{CO}$ & $\mathrm{C} 1$ & $\mathrm{C} 2$ & C3 & & \\
\hline \multicolumn{7}{|l|}{ Intake (g/d) } \\
\hline Lucerne hay DM & 1135 & 1203 & 1070 & 1220 & 91.5 & 0.775 \\
\hline Concentrate DM & 640 & 615 & 530 & 497 & $18 \cdot 1$ & $<0.001$ \\
\hline CaCLA & 0.0 & $28 \cdot 8$ & $50 \cdot 5$ & $74 \cdot 3$ & $3 \cdot 61$ & $<0.001$ \\
\hline$\Sigma \mathrm{DM}$ & 1775 & 1825 & 1650 & 1793 & $75 \cdot 8$ & 0.694 \\
\hline $12: 0$ & $0 \cdot 11$ & 0.11 & $0 \cdot 10$ & 0.11 & 0.008 & 0.860 \\
\hline $14: 0$ & $0 \cdot 18$ & 0.23 & 0.24 & 0.30 & 0.010 & $<0.001$ \\
\hline $16: 0$ & $5 \cdot 13$ & 7.09 & 7.94 & 9.73 & 0.198 & $<0.001$ \\
\hline cis-9-16: 1 & 0.04 & 0.07 & 0.08 & 0.10 & 0.003 & $<0.001$ \\
\hline $18: 0$ & 0.70 & 1.41 & 1.87 & $2 \cdot 48$ & 0.078 & $<0.001$ \\
\hline cis-9-18: 1 & 4.25 & $6 \cdot 74$ & $8 \cdot 24$ & $10 \cdot 2$ & 0.430 & $<0.001$ \\
\hline cis-11-18: 1 & 0.15 & 0.34 & 0.47 & 0.62 & 0.026 & $<0.001$ \\
\hline $18: 2 n-6$ & $9 \cdot 18$ & 9.01 & 7.92 & 7.77 & 0.157 & $<0.001$ \\
\hline cis-9, trans-11 CLA & 0.00 & 7.37 & $13 \cdot 0$ & $19 \cdot 1$ & 0.93 & $<0.001$ \\
\hline trans-10,cis-12 CLA & 0.00 & 6.87 & $12 \cdot 2$ & $17 \cdot 8$ & 0.87 & $<0.001$ \\
\hline$\Sigma$ CLA & 0.00 & $15 \cdot 9$ & $28 \cdot 2$ & $41 \cdot 2$ & $2 \cdot 01$ & $<0.001$ \\
\hline $18: 3 n-3$ & $2 \cdot 52$ & $2 \cdot 63$ & $2 \cdot 34$ & 2.59 & 0.155 & 0.895 \\
\hline $20: 0$ & 0.14 & 0.14 & $0 \cdot 12$ & 0.13 & 0.006 & 0.236 \\
\hline $22: 0$ & 0.12 & 0.19 & 0.23 & 0.29 & 0.006 & $<0.001$ \\
\hline $24: 0$ & $0 \cdot 16$ & 0.17 & $0 \cdot 15$ & $0 \cdot 16$ & 0.009 & 0.641 \\
\hline Other fatty acids & 0.99 & 1.02 & 0.90 & 0.97 & 0.050 & 0.423 \\
\hline$\Sigma$ Fatty acids & 23.9 & $45 \cdot 7$ & $59 \cdot 7$ & 77.9 & $2 \cdot 71$ & $<0.001$ \\
\hline \multicolumn{7}{|l|}{ Yield (g/d) } \\
\hline Milk & 1988 & 1900 & 1850 & 1913 & $67 \cdot 7$ & 0.399 \\
\hline Fat-corrected milk\| & 2198 & 1900 & 1770 & 1740 & $72 \cdot 3$ & 0.004 \\
\hline Fat & $82 \cdot 9$ & $66 \cdot 5$ & $59 \cdot 8$ & $56 \cdot 1$ & $3 \cdot 28$ & 0.001 \\
\hline Protein & $76 \cdot 8$ & $73 \cdot 3$ & $69 \cdot 5$ & $71 \cdot 7$ & $2 \cdot 67$ & $0 \cdot 167$ \\
\hline Lactose & 88.2 & 85.9 & 81.5 & 83.0 & 3.05 & 0.197 \\
\hline \multicolumn{7}{|l|}{ Concentration $(\mathrm{g} / \mathrm{kg})$} \\
\hline Fat & $41 \cdot 9$ & $35 \cdot 1$ & $32 \cdot 4$ & 29.6 & 1.57 & 0.001 \\
\hline Protein & 38.5 & 38.7 & $37 \cdot 6$ & 37.3 & 0.41 & 0.053 \\
\hline Lactose & 44.5 & $45 \cdot 1$ & $44 \cdot 1$ & $43 \cdot 4$ & 0.63 & 0.184 \\
\hline Live weight (kg) & $64 \cdot 1$ & $63 \cdot 8$ & $62 \cdot 4$ & 63.5 & 0.74 & 0.351 \\
\hline
\end{tabular}

CaCLA, calcium salts of conjugated linoleic acid.

* Values represent the mean of days 9 and 10 of treatment.

†Diets based on lucerne hay supplemented with concentrates formulated to supply $0,30,60$ or $90 \mathrm{~g} \mathrm{CaCLA} / \mathrm{d}$ (C0, C1, C2 and $\mathrm{C} 3$, respectively).

$\ddagger$ Standard error of the mean for sixteen measurements; error $\mathrm{df}=6$.

$\S$ Significance of linear responses to CaCLA supplements in the diet. Quadratic and cubic responses to CaCLA were NS $(P>0.05)$.

$\| 35 \mathrm{~g} / \mathrm{kg}$ fat-corrected milk yield $(\mathrm{kg})=$ milk yield $(\mathrm{kg}) \times(313+11.2 \times$ fat content $(\mathrm{g} / \mathrm{kg})) / 704^{(51)}$.

CaCLA in the diet increased linearly $(P<0.001)$ trans-10, cis12 CLA secretion in milk from 14.7 to 139,278 and $219 \mathrm{mg} / \mathrm{d}$ for treatments $\mathrm{C} 1, \mathrm{C} 2$ and $\mathrm{C} 3$, responses associated with a mean apparent efficiency of transfer from the diet into milk of $2.22,2.39$ and $1.69 \%$ (SE $0.381, P=0.634$ ), respectively.

\section{Discussion}

Post-ruminal infusion studies have established a central role of trans-10, cis-12 CLA in the regulation of milk fat synthesis in the lactating $\operatorname{cow}^{(33,34)}$. Reductions in milk fat in response to abomasal infusions of trans-10, cis-12 CLA are known to occur in a predictable dose-dependent manner ${ }^{(32,33)}$. Further research has also demonstrated that post-ruminal infusions of a mixture of CLA isomers containing trans-9, cis-11 $1^{(35)}$ or cis-10, trans-12(36) as major components also exert antilipogenic effects in the bovine. Use of lipid-encapsulated supplements containing cis-9, trans-11 CLA and trans-10, cis-12 CLA has also provided evidence to suggest that the inhibitory effects of trans-10, cis-12 CLA are comparable in the lactating bovine and ovine ${ }^{(37,38)}$. By contrast, short-term administration of trans-10, cis-12 CLA in the peripheral circulation ${ }^{(10)}$ or at the duodenum ${ }^{(11)}$ was reported to have no effect on milk fat synthesis in the lactating goat, suggesting that the anti-lipogenic activity of trans-10, cis-12 CLA differs between ruminant species.

Numerous experiments in lactating cows have established that dietary supplements of calcium salts of a mixture of CLA isomers containing trans-10, cis-12 CLA inhibit milk fat synthesis during early or established lactation over a short or extended period ${ }^{(33)}$. Several studies have demonstrated that the anti-lipogenic potential of trans-10, cis-12 CLA supplied as CaCLA in the diet is lower immediately post-partum in the lactating $\operatorname{cow}^{(6,16,39)}$. Reduced inhibition of mammary lipogenesis does not appear to be related to variations in mammary supply and incorporation of trans-10, cis-12 CLA in milk fat ${ }^{(6,7,16)}$ or specific changes in plasma glucose, insulin, leptin or NEFA concentrations ${ }^{(7,40)}$. It is possible that the coordinated reduction in the expression genes encoding for key lipogenic enzymes to trans-10, cis-12 
Table 4. Effect of dietary conjugated linoleic acid (CLA) supplements on milk fatty acid composition in lactating goats (Experiment $1 ; \mathrm{g} / 100 \mathrm{~g}$ fatty acids)*

\begin{tabular}{|c|c|c|c|c|c|c|c|}
\hline & & & & & & & \\
\hline & CO & C1 & C2 & C3 & SEM $\neq$ & L & Q \\
\hline $4: 0$ & 1.64 & 1.86 & 1.91 & 1.83 & 0.053 & 0.039 & 0.031 \\
\hline $6: 0$ & $2 \cdot 00$ & 1.98 & 1.80 & 1.72 & 0.041 & 0.002 & 0.542 \\
\hline $8: 0$ & $2 \cdot 28$ & $2 \cdot 16$ & 1.84 & 1.73 & 0.067 & $<0.001$ & 0.951 \\
\hline $10: 0$ & 9.86 & 8.97 & 7.42 & $7 \cdot 13$ & 0.349 & $<0.001$ & 0.419 \\
\hline cis-9-10:1 & 0.19 & 0.08 & 0.04 & 0.04 & 0.013 & $<0.001$ & 0.005 \\
\hline $12: 0$ & $6 \cdot 12$ & $5 \cdot 16$ & $4 \cdot 18$ & 4.06 & 0.194 & $<0.001$ & 0.071 \\
\hline $14: 0$ & $13 \cdot 82$ & 14.40 & 13.49 & 13.34 & 0.415 & 0.249 & 0.411 \\
\hline cis-9-14:1 & 0.27 & $0 \cdot 13$ & 0.08 & 0.05 & 0.010 & $<0.001$ & 0.001 \\
\hline $15: 0$ & 1.43 & 1.45 & 1.38 & 1.38 & 0.072 & 0.533 & 0.928 \\
\hline $15: 0$ iso & 0.23 & 0.25 & 0.24 & 0.24 & 0.010 & 0.800 & 0.313 \\
\hline $15: 0$ anteiso & 0.42 & 0.45 & 0.42 & 0.39 & 0.024 & 0.282 & 0.284 \\
\hline $16: 0$ & $29 \cdot 32$ & 27.66 & $26 \cdot 97$ & 27.52 & 0.728 & 0.111 & 0.180 \\
\hline cis-9-16: 1 & 0.83 & 0.49 & 0.43 & 0.37 & 0.028 & $<0.001$ & 0.003 \\
\hline trans-9-16: 1 & 0.07 & 0.13 & 0.21 & 0.27 & 0.031 & 0.003 & 0.986 \\
\hline trans-11-16: 1 & 0.03 & 0.05 & 0.08 & 0.07 & 0.008 & 0.005 & 0.149 \\
\hline $17: 0$ & 0.70 & 0.79 & 0.78 & 0.77 & 0.023 & 0.096 & 0.088 \\
\hline $17: 0$ iso & 0.37 & 0.44 & 0.50 & 0.54 & 0.028 & 0.003 & 0.521 \\
\hline cis-9-17:1 & 0.37 & 0.25 & 0.22 & 0.19 & 0.018 & $<0.001$ & 0.035 \\
\hline $18: 0$ & $6 \cdot 32$ & 9.68 & $12 \cdot 02$ & $11 \cdot 74$ & 0.438 & $<0.001$ & 0.006 \\
\hline cis-9-18: 1 & 15.65 & 11.89 & $11 \cdot 32$ & 9.96 & 0.647 & $<0.001$ & 0.113 \\
\hline cis-11-18: 1 & 0.33 & 0.36 & 0.39 & 0.42 & 0.021 & 0.027 & 0.909 \\
\hline cis-12-18: 1 & 0.15 & 0.45 & 0.54 & 0.55 & 0.044 & $<0.001$ & 0.018 \\
\hline cis-13-18: 1 & 0.02 & 0.03 & 0.03 & 0.03 & 0.006 & 0.311 & 0.251 \\
\hline cis-15-18: $1 \|$ & $0 \cdot 14$ & 0.16 & $0 \cdot 16$ & 0.17 & 0.006 & 0.037 & 0.681 \\
\hline trans-6,7+8-18:1 & 0.07 & 0.20 & 0.27 & 0.31 & 0.023 & $<0.001$ & 0.128 \\
\hline trans-9-18: 1 & 0.15 & 0.31 & 0.40 & 0.45 & 0.036 & $<0.001$ & 0.175 \\
\hline trans-10-18: 1 & 0.20 & $1 \cdot 12$ & 1.56 & 1.99 & 0.166 & $<0.001$ & 0.191 \\
\hline trans-11-18: 1 & 0.41 & 1.32 & 1.93 & $2 \cdot 39$ & 0.199 & $<0.001$ & 0.316 \\
\hline trans-12-18: 1 & $0 \cdot 13$ & 0.36 & 0.52 & 0.59 & 0.051 & $<0.001$ & 0.160 \\
\hline trans $-13+1418: 1$ & 0.25 & 0.60 & 0.83 & 0.94 & 0.067 & $<0.001$ & 0.123 \\
\hline trans-16-18:19 & 0.13 & 0.20 & 0.29 & 0.28 & 0.015 & $<0.001$ & 0.023 \\
\hline$\Sigma$ Cis-18:1 & $16 \cdot 29$ & $12 \cdot 89$ & 12.44 & $11 \cdot 13$ & 0.668 & 0.002 & 0.167 \\
\hline$\Sigma$ Trans-18: 1 & $1 \cdot 34$ & $4 \cdot 11$ & 5.80 & 6.95 & 0.538 & $<0.001$ & 0.185 \\
\hline$\Sigma 18: 1$ & 17.64 & 16.99 & $18 \cdot 24$ & $18 \cdot 08$ & 0.861 & 0.529 & 0.787 \\
\hline $18: 2 n-6$ & 1.83 & 1.75 & 1.82 & 1.75 & 0.057 & 0.511 & 0.911 \\
\hline cis-9, trans-12-18:2 & 0.05 & $0 \cdot 12$ & 0.19 & 0.22 & 0.028 & 0.003 & 0.540 \\
\hline cis-9, trans-13-18:2 & 0.13 & 0.14 & 0.14 & 0.10 & 0.014 & 0.167 & 0.184 \\
\hline$\Sigma C L A$ & 0.47 & 1.53 & 2.69 & 3.77 & 0.409 & $<0.001$ & 0.979 \\
\hline $18: 3 n-3$ & 0.50 & 0.50 & 0.50 & 0.49 & 0.029 & 0.813 & 0.970 \\
\hline $20: 0$ & 0.12 & 0.16 & $0 \cdot 18$ & 0.17 & 0.006 & 0.001 & 0.011 \\
\hline $20: 2 n-6$ & 0.004 & 0.014 & 0.016 & 0.028 & 0.0061 & 0.035 & 0.844 \\
\hline $20: 3 n-6$ & 0.012 & 0.008 & 0.007 & 0.002 & 0.0034 & 0.109 & 0.830 \\
\hline $20: 4 n-6$ & 0.14 & $0 \cdot 10$ & $0 \cdot 10$ & 0.09 & 0.004 & $<0.001$ & 0.014 \\
\hline $20: 5 n-3$ & 0.08 & 0.06 & 0.05 & 0.05 & 0.005 & 0.004 & 0.113 \\
\hline $22: 0$ & 0.04 & 0.06 & 0.06 & 0.06 & 0.005 & 0.042 & 0.154 \\
\hline $22: 5 n-3$ & $0 \cdot 11$ & 0.09 & 0.08 & 0.07 & 0.006 & 0.002 & 0.803 \\
\hline Summary & & & & & & & \\
\hline$\leq \mathrm{C} 14$ & 36.9 & $35 \cdot 3$ & $31 \cdot 2$ & $30 \cdot 4$ & 0.83 & $<0.001$ & 0.687 \\
\hline C16 & $30 \cdot 5$ & $28 \cdot 6$ & $27 \cdot 9$ & $28 \cdot 5$ & 0.70 & 0.076 & 0.131 \\
\hline$\geq \mathrm{C} 18$ & $27 \cdot 4$ & $31 \cdot 2$ & $36 \cdot 1$ & $36 \cdot 7$ & 1.51 & 0.003 & 0.331 \\
\hline$\Sigma$ Saturates & $75 \cdot 7$ & $76 \cdot 4$ & $74 \cdot 0$ & 73.4 & $1 \cdot 12$ & 0.114 & 0.597 \\
\hline$\Sigma$ MUFA & $19 \cdot 4$ & $18 \cdot 1$ & $19 \cdot 3$ & $19 \cdot 1$ & 0.09 & 0.966 & 0.573 \\
\hline$\Sigma$ PUFA & 3.34 & $4 \cdot 31$ & 5.59 & 6.57 & 0.402 & $<0.001$ & 0.981 \\
\hline$\Sigma$ Fatty acids $(\mathrm{g} / 100 \mathrm{~g} \text { fat })^{\star *}$ & $92 \cdot 8$ & 93.2 & 93.3 & 93.6 & 0.131 & 0.006 & 0.583 \\
\hline Ratio & & & & & & & \\
\hline cis-9-10:1:10:0 & 0.019 & 0.009 & 0.005 & 0.005 & 0.0012 & $<0.001$ & 0.004 \\
\hline cis-9-14:1:14:0 & 0.019 & 0.009 & 0.006 & 0.004 & 0.0006 & $<0.001$ & $<0.001$ \\
\hline cis-9-16:1:16:0 & 0.028 & 0.018 & 0.016 & 0.014 & 0.0011 & $<0.001$ & 0.009 \\
\hline cis-9-17:1:17:0 & 0.537 & 0.323 & 0.274 & 0.241 & 0.0223 & $<0.001$ & 0.007 \\
\hline cis-9-18:1:18:0 & 2.547 & 1.231 & 0.956 & 0.860 & 0.1202 & $<0.001$ & 0.002 \\
\hline cis-9,trans-11 CLA:trans-11-18:1 & 0.644 & 0.512 & 0.562 & 0.622 & 0.0275 & 0.898 & 0.013 \\
\hline
\end{tabular}

CaCLA, calcium salts of conjugated linoleic acid.

* Milk fatty acid profile on day 10 of treatment.

† Diets based on lucerne hay supplemented with concentrates formulated to supply $0,30,60$ or $90 \mathrm{~g} \mathrm{CaCLA} / \mathrm{d}$ (C0, C1, C2 and C3, respectively).

$\ddagger$ Standard error of the mean for sixteen measurements; error $\mathrm{df}=6$.

$\S$ Significance of linear $(L)$ and quadratic $(Q)$ responses to CaCLA supplements in the diet. Cubic responses to CaCLA were NS $(P>0.05)$.

II Containing trans-17-18:1 as a minor component.

1) Coeluting with cis-14-18:1 as a minor isomer.

${ }^{\star *}$ Fatty acid content of milk fat calculated assuming that lipid in milk is secreted as TAG. 
Table 5. Effect of dietary conjugated linoleic acid supplements on milk conjugated linoleic acid isomer concentrations in lactating goats (Experiment $1 ; \mathrm{mg} / 100 \mathrm{~g}$ fatty acids)*

\begin{tabular}{|c|c|c|c|c|c|c|}
\hline & \multicolumn{4}{|c|}{ Treatment† } & \multirow[b]{2}{*}{ SEM $¥$} & \multirow[b]{2}{*}{$P \S$} \\
\hline & $\mathrm{CO}$ & $\mathrm{C} 1$ & C2 & C3 & & \\
\hline cis-8, cis-10 & $2 \cdot 7$ & $2 \cdot 9$ & 5.4 & $12 \cdot 2$ & $2 \cdot 89$ & 0.053 \\
\hline cis-9, cis-11 & $6 \cdot 9$ & 34.2 & $57 \cdot 3$ & $82 \cdot 7$ & $8 \cdot 26$ & $<0.001$ \\
\hline cis- 10, cis-12 & $2 \cdot 1$ & 27.9 & $49 \cdot 4$ & $68 \cdot 8$ & $6 \cdot 70$ & $<0.001$ \\
\hline cis-9, trans-11 & 265 & 658 & 1073 & 1459 & $135 \cdot 2$ & $<0.001$ \\
\hline cis- 11 , trans-13 & $56 \cdot 8$ & $16 \cdot 6$ & $29 \cdot 7$ & $44 \cdot 0$ & $30 \cdot 04$ & 0.856 \\
\hline trans-7, cis-9 & $20 \cdot 1$ & $26 \cdot 7$ & 33.6 & $36 \cdot 5$ & 3.09 & 0.007 \\
\hline trans -8, cis- 10 & $13 \cdot 2$ & $52 \cdot 2$ & 94.9 & 139 & $13 \cdot 76$ & $<0.001$ \\
\hline trans -9, cis-11 & $15 \cdot 5$ & 35.7 & $56 \cdot 5$ & $77 \cdot 3$ & $10 \cdot 93$ & $<0.001$ \\
\hline trans -10, cis-12 & $18 \cdot 4$ & 260 & 530 & 810 & $90 \cdot 3$ & $<0.001$ \\
\hline trans-11, cis-13 & $6 \cdot 1$ & $2 \cdot 7$ & $4 \cdot 2$ & $5 \cdot 9$ & 3.09 & 0.967 \\
\hline trans-12, cis-14 & 0.8 & 3.6 & 4.6 & $6 \cdot 1$ & 1.48 & 0.042 \\
\hline trans -13, cis-15 & 1.6 & 3.5 & 4.6 & $6 \cdot 7$ & 0.97 & 0.009 \\
\hline trans- 6 , trans-8 & 5.8 & 44.1 & 84.6 & 118 & 14.77 & 0.001 \\
\hline trans- 7, trans -9 & $3 \cdot 1$ & $20 \cdot 2$ & $41 \cdot 8$ & $56 \cdot 1$ & 6.69 & $<0.001$ \\
\hline trans -8, trans -10 & $2 \cdot 3$ & $19 \cdot 4$ & $28 \cdot 8$ & $40 \cdot 0$ & 3.74 & $<0.001$ \\
\hline trans -9 , trans -11 & $18 \cdot 8$ & 139 & 254 & 353 & 43.3 & 0.001 \\
\hline trans -10, trans -12 & $13 \cdot 9$ & 148 & 270 & 366 & 41.7 & $<0.001$ \\
\hline trans -11, trans -13 & $7 \cdot 7$ & 24.7 & 49.5 & 68.4 & $9 \cdot 11$ & 0.002 \\
\hline trans -12, trans -14 & $9 \cdot 1$ & 9.7 & $15 \cdot 1$ & $19 \cdot 2$ & 3.08 & 0.041 \\
\hline
\end{tabular}

CaCLA, calcium salts of conjugated linoleic acid.

* Milk fatty acid profile on day 10 of treatment.

† Diets based on lucerne hay supplemented with concentrates formulated to supply $0,30,60$ or $90 \mathrm{~g} \mathrm{CaCLA} / \mathrm{d}$ (C0, C1, C2 and $\mathrm{C} 3$, respectively).

$\ddagger$ Standard error of the mean for sixteen measurements; error $\mathrm{df}=6$

$\S$ Significance of linear responses to CaCLA supplements in the diet. Quadratic and cubic responses to CaCLA were NS $(P>0.05)$.

CLA is prevented due to the attenuation of cellular signalling systems during the onset of lactation ${ }^{(6,16)}$. A lower sensitivity of mammary lipogenesis to trans-10, cis-12 CLA during early lactation in the bovine is analogous to the response to trans-10, cis-12 CLA infusion in the goat $^{(10,11)}$, suggesting some common features in the regulation of mammary lipid metabolism. However, there are also several distinct differences between species: (i) decreases in milk fat synthesis in the bovine during early lactation involve a reduction in fatty acids synthesised de novo and preformed fatty acids, whereas reductions in milk fat synthesis to CaCLA in the goat were confined to $\leq \mathrm{C} 14$ and $\mathrm{C} 16$ fatty acids (Fig. 1), (ii) comparisons between experiments indicated that the

(a)

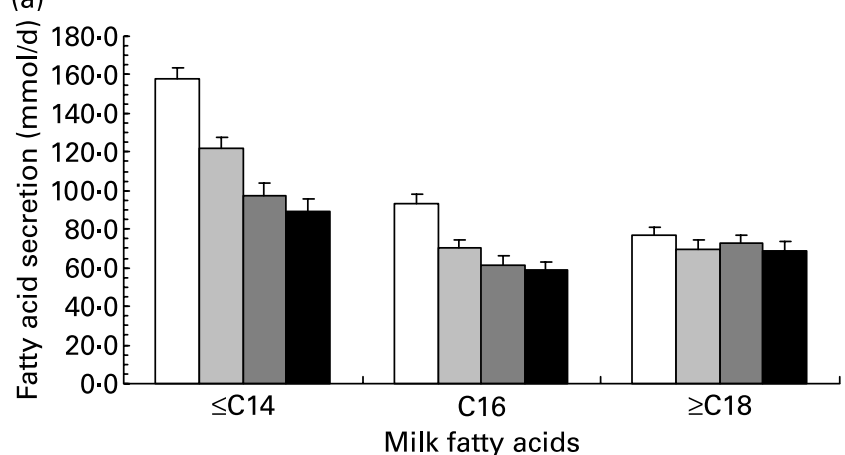

inhibitory effects of CaCLA on milk fat synthesis in the goat are dependent on the supply of long-chain fatty acids (Fig. 2), whereas limited data in the lactating cow suggest that responses to trans-10, cis-12 CLA are independent of dietary fatty acid content ${ }^{(41)}$ and (iii) a lower sensitivity to trans-10, cis-12 CLA in the bovine also coincides with alterations in several key enzymes and biochemical pathways at the onset of lactation and is a transitory phenomenon, whereas the lower sensitivity in the goat occurs in established lactation during periods of positive energy and nitrogen balance (Fig. 3)

The present experiment provided further evidence that CaCLA supplements also decrease milk fat content and (b)

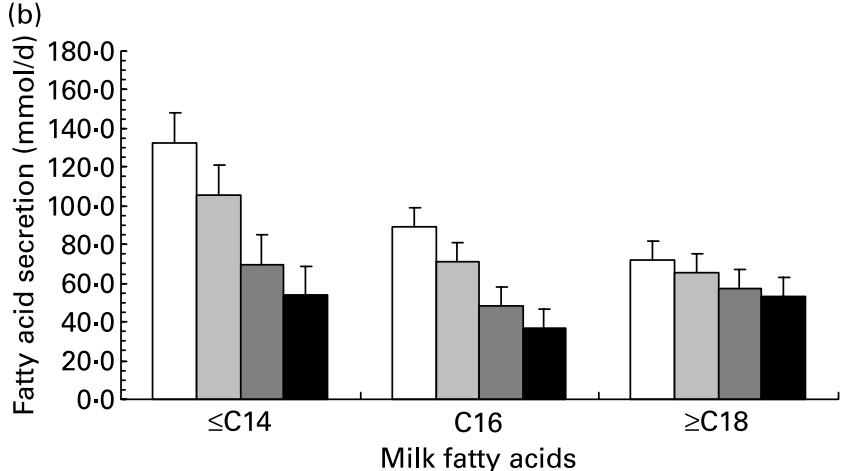

Fig. 1. Milk fatty acid secretion in goats measured on day 10 of treatment in response to (a) $0,30,60$ or $90 \mathrm{~g}$ calcium salts of conjugated linoleic acid (CLA)/d in

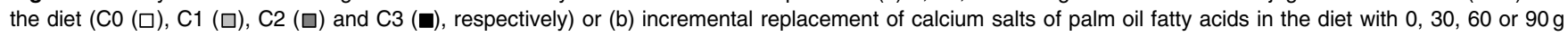
calcium salts of CLA/d (CP0 ( $\square$ ), CP1 ( $\square$ ), CP2 ( $\square$ ) and CP3 ( $\square$ ), respectively). Fatty acids in milk categorised according to metabolic origin: $\leq$ C14 synthesised de novo; $\geq \mathrm{C} 18$ extracted and incorporated into milk fat from circulating plasma lipids; C16 derived from both sources. For both experiments, dietary supplements of calcium salts of CLA decreased linearly $(P<0.01) \leq \mathrm{C} 14$ and $\geq \mathrm{C} 16$ output but had no effect $(P>0.05)$ on $\geq \mathrm{C} 18$ secretion in milk. Quadratic and cubic responses to experimental treatments were NS $(P>0.05)$. Error bars indicate standard errors of the mean for sixteen measurements. 
Table 6. Effect of replacing calcium salts of palm oil fatty acids in the diet with supplements of conjugated linoleic acid (CLA) on nutrient intake, milk production and live weight in lactating goats (Experiment 2$)^{\star}$

\begin{tabular}{|c|c|c|c|c|c|c|}
\hline & \multicolumn{4}{|c|}{ Treatment† } & \multirow[b]{2}{*}{ SEM } & \multirow[b]{2}{*}{$P \S$} \\
\hline & CPO & $\mathrm{CP} 1$ & CP2 & CP3 & & \\
\hline \multicolumn{7}{|l|}{ Intake (g/d) } \\
\hline Lucerne hay DM & 1180 & 1250 & 1208 & 1018 & $121 \cdot 2$ & 0.368 \\
\hline Concentrate DM & 510 & 518 & 473 & 433 & $32 \cdot 9$ & 0.108 \\
\hline $\mathrm{CaPO}$ & $76 \cdot 3$ & $52 \cdot 3$ & 23.5 & 0.0 & $2 \cdot 30$ & $<0.001$ \\
\hline CaCLA & 0.0 & $26 \cdot 0$ & $46 \cdot 3$ & $63 \cdot 0$ & 4.89 & $<0.001$ \\
\hline$\Sigma \mathrm{DM}$ & 1765 & 1848 & 1748 & 1515 & $154 \cdot 7$ & 0.269 \\
\hline $12: 0$ & 0.38 & 0.30 & 0.19 & 0.09 & 0.017 & $<0.001$ \\
\hline $14: 0$ & 1.25 & 0.96 & 0.58 & 0.25 & 0.049 & $<0.001$ \\
\hline $16: 0$ & 38.2 & 29.5 & 17.9 & $8 \cdot 26$ & 1.45 & $<0.001$ \\
\hline cis-9-16: 1 & 0.16 & 0.14 & 0.11 & 0.09 & 0.009 & $<0.001$ \\
\hline $18: 0$ & 3.09 & 2.98 & 2.52 & $2 \cdot 11$ & 0.206 & 0.010 \\
\hline cis-9-18: 1 & $25 \cdot 6$ & $21 \cdot 0$ & $14 \cdot 2$ & $8 \cdot 77$ & 1.081 & $<0.001$ \\
\hline cis-11-18:1 & 0.12 & 0.30 & 0.43 & 0.53 & 0.041 & $<0.001$ \\
\hline $18: 2 n-6$ & $13 \cdot 0$ & 11.5 & 8.98 & $6 \cdot 77$ & 0.624 & $<0.001$ \\
\hline cis-9,trans-11 CLA & 0.00 & $6 \cdot 68$ & 11.9 & $16 \cdot 1$ & 1.255 & $<0.001$ \\
\hline trans -10, cis-12 CLA & 0.00 & 6.23 & 11.1 & $15 \cdot 1$ & $1 \cdot 170$ & $<0.001$ \\
\hline$\Sigma \mathrm{CLA}$ & 0.00 & 14.4 & $25 \cdot 7$ & 34.9 & $2 \cdot 71$ & $<0.001$ \\
\hline $18: 3 n-3$ & 2.69 & $2 \cdot 78$ & $2 \cdot 60$ & $2 \cdot 17$ & 0.246 & 0.169 \\
\hline $20: 0$ & 0.25 & 0.22 & 0.16 & 0.11 & 0.014 & $<0.001$ \\
\hline $22: 0$ & 0.12 & 0.18 & 0.22 & 0.25 & 0.021 & 0.004 \\
\hline $24: 0$ & 0.16 & 0.17 & 0.16 & 0.14 & 0.015 & 0.307 \\
\hline Other fatty acids & 1.65 & 1.47 & $1 \cdot 16$ & 0.82 & 0.099 & $<0.001$ \\
\hline$\Sigma$ Fatty acids & 86.9 & 86.6 & $75 \cdot 7$ & $66 \cdot 3$ & $6 \cdot 12$ & 0.037 \\
\hline \multicolumn{7}{|l|}{ Yield (g/d) } \\
\hline Milk & 1650 & 1813 & 1488 & 1413 & $115 \cdot 2$ & 0.091 \\
\hline Fat-corrected milk\| & 1905 & 1773 & 1375 & 1223 & $179 \cdot 7$ & 0.023 \\
\hline Fat & 73.8 & $60 \cdot 9$ & $45 \cdot 0$ & 37.4 & $8 \cdot 33$ & 0.015 \\
\hline Protein & 59.9 & $65 \cdot 0$ & $54 \cdot 2$ & $50 \cdot 7$ & 4.02 & 0.076 \\
\hline Lactose & 71.1 & $77 \cdot 7$ & $63 \cdot 3$ & $61 \cdot 2$ & $5 \cdot 27$ & 0.111 \\
\hline \multicolumn{7}{|l|}{ Concentration $(\mathrm{g} / \mathrm{kg})$} \\
\hline Fat & $44 \cdot 1$ & 33.5 & 29.2 & $28 \cdot 3$ & $2 \cdot 61$ & 0.005 \\
\hline Protein & $36 \cdot 6$ & $36 \cdot 6$ & 37.1 & $36 \cdot 3$ & 0.52 & 0.832 \\
\hline Lactose & $42 \cdot 9$ & $42 \cdot 1$ & 40.6 & $42 \cdot 6$ & 0.68 & 0.463 \\
\hline Live weight (kg) & 61.1 & $60 \cdot 4$ & 58.9 & 59.4 & 0.74 & 0.091 \\
\hline
\end{tabular}

CaCLA, calcium salts of CLA; CaPO, calcium salts of palm oil fatty acids

*Values represent the mean of days 9 and 10 of treatment.

†Diets based on lucerne hay supplemented with concentrates containing calcium salts of palm oil fatty acids that were replaced incrementally with calcium salts of conjugated linoleic acid to supply $0,30,60$ or $90 \mathrm{~g} \mathrm{CaCLA} / \mathrm{d}$ (CP0, CP1, $\mathrm{CP} 2$ and $\mathrm{CP} 3$, respectively).

$\mp$ Standard error of the mean for sixteen measurements; error $\mathrm{df}=6$.

$\S$ Significance of linear responses to CaCLA supplements in the diet. Quadratic and cubic responses to CaCLA were NS $(P>0.05)$.

$\| 35 \mathrm{~g} / \mathrm{kg}$ fat-corrected milk yield $(\mathrm{kg})=$ milk yield $(\mathrm{kg}) \times(313+11.2 \times$ fat content $(\mathrm{g} / \mathrm{kg})) / 704^{(51)}$

yield in the lactating goat in a dose-dependent manner (Fig. 2). A specific reduction in milk fat secretion in the absence of changes in milk yield, milk protein content or lactose concentrations is consistent with typical milk production responses to CaCLA reported for lactating cows over short or extended periods $^{(42)}$. However, the changes in milk fat synthesis were dependent on CaCLA supplementation regimen. Increases in trans-10, cis-12 CLA intake from CaCLA in Experiment 1 were associated with a curvilinear decrease in milk fat yield and content, whereas in Experiment 2, CaCLA treatments resulted in a linear decrease in milk fat yield and a curvilinear reduction in milk fat content (Fig. 2).

Relative reductions in milk fat secretion were larger when CaCLA replaced $\mathrm{CaPO}$ in the diet than when offered alone, which can be attributed to incremental replacement of $\mathrm{CaPO}$ with CaCLA resulting in marginal linear reductions in total fatty acid intake (Table 6), arising at least in part, from nonsignificant decreases in DM intake. Inclusion of CaCLA in the diet enhanced linearly dietary fatty acid intake, with the implication that the supply of 18:0 available for absorption was also increased due to extensive metabolism of the CaCLA supplement in the rumen as inferred from a low transfer of trans-10, cis-12 CLA into milk. In marked contrast to the bovine, increases in the supply of dietary fatty acids are known to enhance milk fat content in the goat ${ }^{(8,9)}$, indicating that alterations in dietary fatty acid supply may also contribute to between-experiment variation in milk fat responses to CaCLA. Milk fat content was higher $(2 \cdot 2 \mathrm{~g} / \mathrm{kg})$ for $\mathrm{C} 0$ than for $\mathrm{CP0}$ treatments. Accounting for measured differences in milk composition between animals assigned to experiments indicated that $\mathrm{CaPO}$ in the diet elicited a mean $4.3 \mathrm{~g} / \mathrm{kg}$ increase in milk fat concentrations consistent with responses of $3.7-5 \cdot 2 \mathrm{~g} / \mathrm{kg}$ reported in the literature ${ }^{(8)}$. Due to the critical role of fatty acid supply in the regulation of mammary lipogenesis in the caprine, the changes in milk fat content and secretion to substituting $\mathrm{CaPO}$ for CaCLA in the diet can be 
Table 7. Effect of replacing calcium salts of palm oil fatty acids in the diet with supplements of conjugated linoleic acid (CLA) on milk fatty acid composition in lactating goats (Experiment 2; g/100 g fatty acids) ${ }^{*}$

\begin{tabular}{|c|c|c|c|c|c|c|c|c|}
\hline & \multicolumn{4}{|c|}{ Treatment $†$} & \multirow[b]{2}{*}{ SEM‡ } & \multicolumn{3}{|c|}{$P \S$} \\
\hline & CPO & CP1 & CP2 & CP3 & & $\mathrm{L}$ & $Q$ & C \\
\hline $4: 0$ & 1.61 & $2 \cdot 13$ & 2.04 & $2 \cdot 01$ & 0.092 & 0.036 & 0.024 & 0.154 \\
\hline $6: 0$ & $2 \cdot 24$ & $2 \cdot 10$ & 1.82 & 1.73 & 0.148 & 0.034 & 0.863 & 0.641 \\
\hline $8: 0$ & 2.56 & $2 \cdot 14$ & $1 \cdot 78$ & 1.65 & 0.191 & 0.011 & 0.488 & 0.835 \\
\hline $10: 0$ & 10.08 & $8 \cdot 33$ & 6.98 & $6 \cdot 19$ & 0.820 & 0.012 & 0.581 & 0.963 \\
\hline cis-9-10: 1 & 0.30 & 0.08 & 0.06 & 0.07 & 0.017 & $<0.001$ & $<0.001$ & 0.077 \\
\hline $12: 0$ & 5.69 & 4.54 & $4 \cdot 14$ & 3.55 & 0.561 & 0.034 & 0.631 & 0.718 \\
\hline $14: 0$ & $12 \cdot 17$ & 13.45 & $13 \cdot 24$ & 11.39 & 1.394 & 0.698 & 0.304 & 0.984 \\
\hline cis-9-14: 1 & 0.33 & 0.11 & 0.10 & 0.10 & 0.022 & $<0.001$ & 0.003 & 0.099 \\
\hline $15: 0$ & $1 \cdot 14$ & 1.04 & 1.04 & 1.03 & 0.087 & 0.422 & 0.637 & 0.788 \\
\hline $15: 0$ iso & 0.16 & 0.17 & 0.17 & 0.18 & 0.009 & 0.262 & 0.985 & 0.866 \\
\hline $15: 0$ anteiso & 0.27 & 0.30 & 0.27 & 0.29 & 0.025 & 0.909 & 0.889 & 0.405 \\
\hline $16: 0$ & 31.25 & 30.59 & 28.39 & 25.53 & 1.062 & 0.007 & 0.339 & 0.859 \\
\hline cis-9-16: 1 & 1.00 & 0.46 & 0.46 & 0.51 & 0.044 & $<0.001$ & $<0.001$ & 0.051 \\
\hline trans-9-16: 1 & 0.06 & 0.09 & 0.16 & 0.22 & 0.025 & 0.003 & 0.572 & 0.647 \\
\hline trans-11-16:1 & 0.02 & 0.05 & 0.06 & 0.08 & 0.008 & 0.001 & 0.533 & 0.486 \\
\hline $17: 0$ & 0.45 & 0.62 & 0.70 & 0.85 & 0.102 & 0.032 & 0.918 & 0.757 \\
\hline $17: 0$ iso & 0.25 & 0.32 & 0.37 & 0.46 & 0.025 & $<0.001$ & 0.635 & 0.692 \\
\hline cis-9-17: 1 & 0.25 & 0.16 & 0.21 & 0.27 & 0.052 & 0.673 & 0.220 & 0.654 \\
\hline $18: 0$ & $4 \cdot 81$ & $8 \cdot 86$ & 10.57 & $12 \cdot 33$ & 0.953 & 0.001 & 0.272 & 0.596 \\
\hline cis-9-18: 1 & $17 \cdot 47$ & $14 \cdot 17$ & 14.22 & $16 \cdot 62$ & 3.050 & 0.861 & 0.386 & 0.944 \\
\hline cis-11-18: 1 & 0.31 & 0.34 & 0.38 & 0.43 & 0.027 & 0.014 & 0.770 & 0.972 \\
\hline cis-12-18: 1 & 0.13 & 0.35 & 0.51 & 0.56 & 0.063 & 0.002 & 0.260 & 0.872 \\
\hline cis-13-18: 1 & 0.03 & 0.02 & 0.02 & 0.04 & 0.004 & 0.308 & 0.008 & 0.394 \\
\hline cis-15-18:1\| & 0.11 & 0.12 & 0.13 & 0.15 & 0.009 & 0.017 & 0.550 & 0.689 \\
\hline trans-6,7 $+8-18: 1$ & 0.11 & 0.19 & 0.22 & 0.27 & 0.029 & 0.008 & 0.690 & 0.633 \\
\hline trans-9-18: 1 & 0.19 & 0.30 & 0.37 & 0.46 & 0.020 & $<0.001$ & 0.619 & 0.554 \\
\hline trans-10-18: 1 & 0.22 & 0.78 & $1 \cdot 21$ & 1.42 & 0.161 & 0.001 & 0.300 & 0.897 \\
\hline trans-11-18: 1 & 0.35 & 0.82 & $1 \cdot 32$ & $1 \cdot 75$ & 0.180 & 0.001 & 0.908 & 0.880 \\
\hline trans-12-18: 1 & 0.13 & 0.30 & 0.40 & 0.51 & 0.046 & 0.001 & 0.528 & 0.750 \\
\hline trans-13 $+1418: 1$ & 0.27 & 0.57 & 0.69 & 0.81 & 0.069 & 0.001 & 0.255 & 0.573 \\
\hline trans-16-18:11 & 0.12 & 0.17 & 0.22 & 0.28 & 0.013 & $<0.001$ & 0.804 & 0.647 \\
\hline$\Sigma$ cis $-18: 1$ & 18.05 & 14.99 & $15 \cdot 26$ & $17 \cdot 80$ & 3.031 & 0.973 & 0.391 & 0.941 \\
\hline$\sum$ trans-18: 1 & 1.39 & $3 \cdot 13$ & 4.44 & $5 \cdot 50$ & 0.494 & $<0.001$ & 0.512 & 0.938 \\
\hline$\Sigma 18: 1$ & $19 \cdot 44$ & $18 \cdot 13$ & $19 \cdot 70$ & 23.30 & 2.657 & 0.311 & 0.390 & 0.944 \\
\hline $18: 2 n-6$ & $2 \cdot 19$ & $2 \cdot 29$ & $2 \cdot 39$ & 2.42 & 0.160 & 0.306 & 0.816 & 0.923 \\
\hline cis-9, trans-12-18:2 & 0.05 & 0.09 & 0.14 & 0.17 & 0.011 & $<0.001$ & 0.951 & 0.596 \\
\hline cis-9, trans-13-18:2 & 0.12 & 0.11 & 0.12 & 0.14 & 0.011 & 0.188 & 0.146 & 0.804 \\
\hline$\Sigma \mathrm{CLA}$ & 0.45 & $1 \cdot 38$ & $2 \cdot 62$ & $2 \cdot 90$ & 0.298 & $<0.001$ & 0.322 & 0.380 \\
\hline $18: 3 n-3$ & 0.40 & 0.47 & 0.53 & 0.54 & 0.041 & 0.034 & 0.516 & 0.802 \\
\hline $20: 0$ & 0.10 & 0.14 & 0.14 & 0.14 & 0.007 & 0.019 & 0.032 & 0.374 \\
\hline $20: 2 n-6$ & 0.008 & 0.017 & 0.022 & 0.024 & 0.0024 & 0.003 & 0.248 & 0.888 \\
\hline $20: 3 n-6$ & 0.010 & 0.007 & $<0.001$ & 0.006 & 0.0032 & 0.213 & 0.216 & 0.283 \\
\hline $20: 4 n-6$ & 0.12 & 0.10 & 0.10 & $0 \cdot 10$ & 0.004 & 0.028 & 0.097 & 0.049 \\
\hline $20: 5 n-3$ & 0.06 & 0.05 & 0.05 & 0.05 & 0.005 & 0.165 & 0.319 & 0.575 \\
\hline $22: 0$ & 0.02 & 0.03 & 0.03 & 0.03 & 0.002 & 0.017 & 0.078 & 0.285 \\
\hline $22: 5 n-3$ & 0.08 & 0.07 & 0.08 & 0.07 & 0.004 & 0.358 & 0.980 & 0.218 \\
\hline \multicolumn{9}{|l|}{ Summary } \\
\hline$\leq \mathrm{C} 14$ & $35 \cdot 6$ & $33 \cdot 3$ & 30.6 & $27 \cdot 0$ & 2.93 & 0.072 & 0.845 & 0.979 \\
\hline C16 & 32.5 & 31.4 & $29 \cdot 3$ & $26 \cdot 5$ & 1.03 & 0.005 & 0.472 & 0.928 \\
\hline$\geq \mathrm{C} 18$ & 27.9 & 31.7 & 36.5 & $42 \cdot 3$ & 3.48 & 0.022 & 0.794 & 0.995 \\
\hline$\Sigma$ Saturates & 73.7 & $75 \cdot 4$ & $72 \cdot 3$ & 68.0 & $2 \cdot 61$ & 0.135 & 0.289 & 0.770 \\
\hline$\Sigma$ MUFA & 21.4 & $19 \cdot 1$ & 20.7 & 24.5 & 2.69 & 0.394 & 0.297 & 0.883 \\
\hline$\Sigma$ PUFA & 3.49 & 4.56 & 6.03 & 6.42 & 0.215 & $<0.001$ & 0.165 & 0.170 \\
\hline$\Sigma$ Fatty acids $(\mathrm{g} / 100 \mathrm{~g} \text { fat })^{\star \star}$ & 92.9 & 93.5 & 93.6 & 93.5 & 0.117 & 0.010 & 0.052 & 0.764 \\
\hline \multicolumn{9}{|l|}{ Ratio } \\
\hline cis-9-10:1:10:0 & 0.030 & 0.009 & 0.008 & 0.012 & 0.0013 & $<0.001$ & $<0.001$ & 0.052 \\
\hline cis-9-14: $1: 14: 0$ & 0.027 & 0.008 & 0.007 & 0.009 & 0.0013 & $<0.001$ & $<0.001$ & 0.059 \\
\hline cis-9-16:1:16:0 & 0.032 & 0.015 & 0.016 & 0.021 & 0.0020 & 0.010 & 0.002 & 0.175 \\
\hline cis-9-17:1:17:0 & 0.568 & 0.262 & 0.291 & 0.298 & 0.0302 & 0.001 & 0.002 & 0.039 \\
\hline cis-9-18:1:18:0 & 3.807 & 1.622 & 1.414 & 1.313 & 0.2351 & $<0.001$ & 0.004 & 0.126 \\
\hline cis-9, trans-11 CLA:trans-11-18:1 & 0.902 & 0.750 & 0.884 & 0.780 & 0.0355 & 0.194 & 0.517 & 0.016 \\
\hline
\end{tabular}

CaCLA, calcium salts of conjugated linoleic acid.

${ }^{*}$ Milk fatty acid profile on day 10 of treatment.

†Diets based on lucerne hay supplemented with concentrates containing calcium salts of palm oil fatty acids that were replaced incrementally with calcium salts of conjugated linoleic acid to supply $0,30,60$ or $90 \mathrm{~g} \mathrm{CaCLA} / \mathrm{d}$ (CP0, CP1, CP2 and CP3, respectively).

$\mp$ Standard error of the mean for sixteen measurements; error $\mathrm{df}=6$.

$\S$ Significance of linear $(L)$, quadratic $(Q)$ and cubic $(C)$ responses to CaCLA supplements in the diet.

|| Containing trans-17-18:1 as a minor component.

- Coeluting with cis-14-18:1 as a minor isomer.

${ }^{\star \star}$ Fatty acid content of milk fat calculated assuming that lipid in milk is secreted as TAG. 
Table 8. Effect of replacing calcium salts of palm oil fatty acids with supplements of conjugated linoleic acid on milk conjugated linoleic acid isomer concentrations in lactating goats (Experiment 2; $\mathrm{mg} / 100 \mathrm{~g}$ fatty acids) ${ }^{\star}$

\begin{tabular}{|c|c|c|c|c|c|c|c|}
\hline & \multicolumn{4}{|c|}{ Treatment† } & \multirow[b]{2}{*}{ SEM‡ } & \multicolumn{2}{|c|}{$P \S$} \\
\hline & CPO & $\mathrm{CP} 1$ & CP2 & CP3 & & L & Q \\
\hline cis-8, cis-10 & 0.4 & $4 \cdot 8$ & 5.5 & 5.5 & 0.90 & 0.007 & 0.048 \\
\hline cis-9,cis-11 & 4.8 & $31 \cdot 2$ & 59.5 & $63 \cdot 2$ & 7.98 & 0.001 & 0.204 \\
\hline cis-10, cis-12 & $2 \cdot 0$ & 23.5 & $46 \cdot 0$ & $46 \cdot 3$ & $7 \cdot 13$ & 0.003 & 0.188 \\
\hline cis-9,trans-11 & 310 & 607 & 1142 & 1316 & 101.9 & $<0.001$ & 0.568 \\
\hline cis-11,trans-13 & 1.9 & $15 \cdot 2$ & $32 \cdot 7$ & 37.5 & 3.69 & $<0.001$ & 0.296 \\
\hline trans-7,cis-9 & 31.9 & $26 \cdot 7$ & $32 \cdot 8$ & 43.8 & 3.26 & 0.028 & 0.049 \\
\hline trans -8, cis- 10 & $11 \cdot 1$ & $47 \cdot 6$ & 103 & 109 & $11 \cdot 27$ & $<0.001$ & 0.229 \\
\hline trans-9, cis- 11 & $13 \cdot 3$ & $26 \cdot 8$ & $45 \cdot 8$ & $68 \cdot 6$ & 5.44 & $<0.001$ & 0.429 \\
\hline trans-10,cis-12 & $20 \cdot 6$ & 248 & 571 & 580 & $87 \cdot 8$ & 0.002 & 0.259 \\
\hline trans $-11, c i s-13$ & 1.4 & $2 \cdot 2$ & 4.2 & 3.3 & 0.83 & 0.086 & 0.345 \\
\hline trans-12,cis-14 & $0 \cdot 1$ & 1.8 & 3.9 & $5 \cdot 3$ & 0.80 & 0.003 & 0.918 \\
\hline trans-13,cis-15 & 1.0 & $2 \cdot 3$ & $3 \cdot 3$ & $6 \cdot 1$ & 0.71 & 0.002 & 0.325 \\
\hline trans-6,trans-8 & $4 \cdot 8$ & $38 \cdot 3$ & $66 \cdot 2$ & $76 \cdot 3$ & $6 \cdot 91$ & $<0.001$ & 0.139 \\
\hline trans-7,trans -9 & $2 \cdot 3$ & $16 \cdot 6$ & $31 \cdot 8$ & $36 \cdot 8$ & 4.82 & 0.002 & 0.369 \\
\hline trans-8,trans-10 & $5 \cdot 1$ & $16 \cdot 6$ & $23 \cdot 4$ & $25 \cdot 8$ & $3 \cdot 28$ & 0.003 & $0 \cdot 211$ \\
\hline trans-9,trans-11 & $16 \cdot 3$ & 115 & 182 & 199 & $28 \cdot 6$ & 0.003 & 0.203 \\
\hline trans-10,trans- 12 & $10 \cdot 9$ & 125 & 214 & 227 & $33 \cdot 0$ & 0.003 & $0 \cdot 177$ \\
\hline trans -11 , trans -13 & $3 \cdot 2$ & $20 \cdot 9$ & 38.4 & $40 \cdot 8$ & $6 \cdot 36$ & 0.004 & 0.275 \\
\hline trans-12,trans-14 & 3.5 & $7 \cdot 7$ & $10 \cdot 9$ & $13 \cdot 4$ & 1.90 & 0.008 & 0.679 \\
\hline
\end{tabular}

CaCLA, calcium salts of conjugated linoleic acid.

${ }^{*}$ Milk fatty acid profile on day 10 of treatment.

†Diets based on lucerne hay supplemented with concentrates containing calcium salts of palm oil fatty acids that were replaced incrementally with calcium salts of conjugated linoleic acid to supply $0,30,60$ or $90 \mathrm{~g} \mathrm{CaCLA} / \mathrm{d}$ (CP0, CP1, CP2 and $\mathrm{CP} 3$, respectively).

¥ Standard error of the mean for sixteen measurements; error $\mathrm{df}=6$.

$\S$ Significance of linear $(\mathrm{L})$ and quadratic $(\mathrm{Q})$ responses to CaCLA supplements in the diet. Cubic responses to CaCLA were NS $(P>0.05)$

considered to be a close reflection of the anti-lipogenic potential of CaCLA supplements in the lactating goat.

CaCLA supplements contained several CLA isomers including trans-10, cis-12 CLA and cis-9, trans-11 CLA as major components. Due to a lack of experimental data in the goat, inferences on the possible contribution of constituent isomers to the observed reductions in milk fat have been drawn based on evidence from studies in the lactating cow. Post-ruminal infusion experiments have established that cis-9, trans-11 CLA, cis-11, trans-13 CLA, trans-8, cis-10 CLA, trans-9, trans-11 CLA and trans-10, trans-12 CLA are not involved in the regulation of milk fat synthesis in the bovine ${ }^{(33)}$. Inclusion of

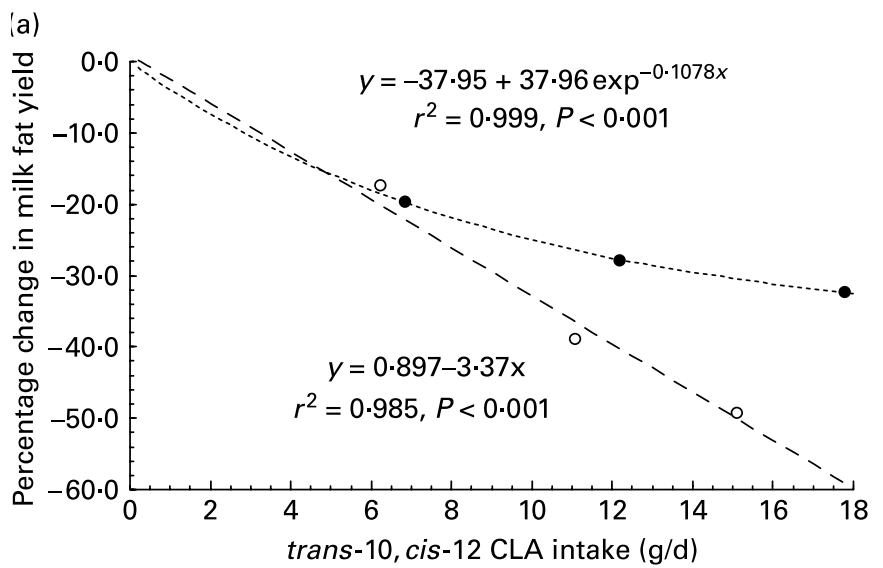

CaCLA in the diet was also associated with linear increases in milk fat trans-18:1 ( $\Delta 6-16)$ and cis-18:1 ( $\Delta 11,12$ and 15$)$ concentrations. Administration of trans $-9,-10,-11$ and -12-18:1 and cis-11 and -12-18:1 at the duodenum have been shown to have no effect on milk fat synthesis in the lactating cows ${ }^{(33)}$, while recent evaluations have in some ${ }^{(43)}$, but not all, cases $^{(25)}$ suggested trans-7-18:1 as a putative milk fat inhibitor. Overall, a detailed analysis of the lipid composition of the CaCLA supplement coupled with the evidence from studies in lactating cows provides support for trans-10, cis-12 CLA being responsible for the reductions in milk fat synthesis in the goat determined in the present study, consistent with the

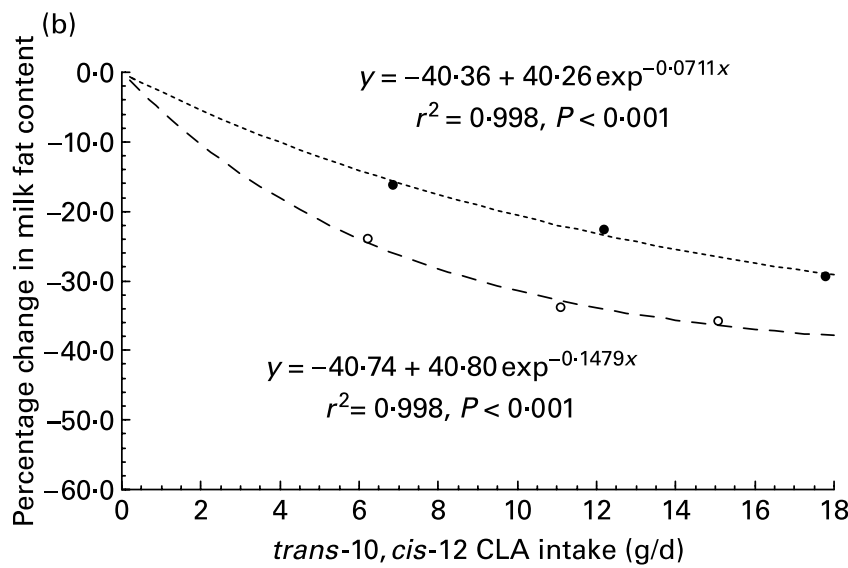

Fig. 2. Relationship between the percentage reduction in (a) milk fat yield and (b) milk fat content in lactating goats relative to a control diet in response to trans-10, cis-12 CLA intake. Treatments comprised calcium salts of CLA (-; experiment 1) or incremental replacement of calcium salts of palm oil fatty acids in the diet with calcium salts of CLA (O; experiment 2). For both experiments, symbols represent least-squares means $(n 4)$. 
(a)

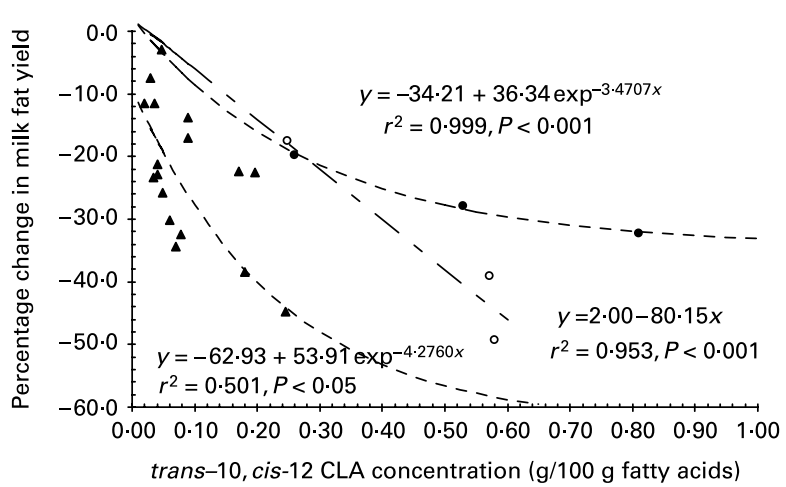

(b)

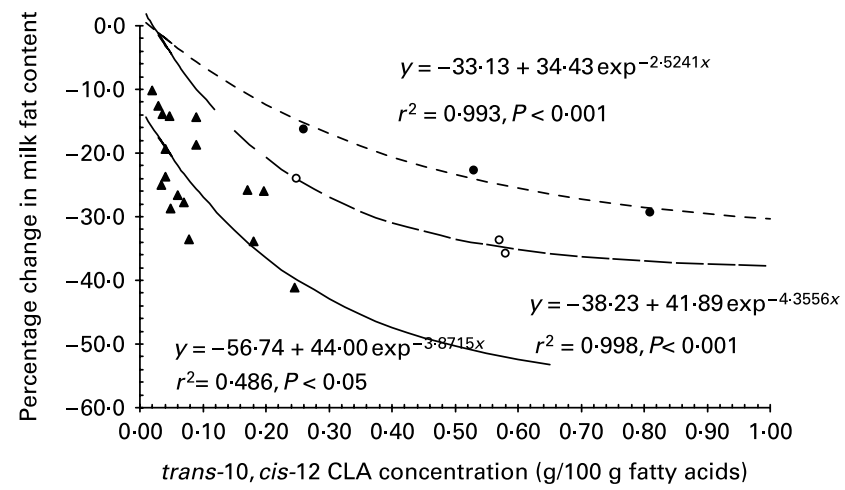

Fig. 3. Relationship between the percentage reduction in (a) milk fat yield and (b) milk fat content with milk fat trans-10,cis-12 CLA concentration in lactating goats relative to responses determined in lactating cows. Treatments comprised calcium salts of CLA ( $\bullet$; experiment 1$)$ or incremental replacement of calcium salts of palm oil fatty acids in the diet with calcium salts of CLA (O; experiment 2). Symbols for experiments 1 and 2 represent least-squares means $(n 4)$. Data in lactating cows $(\boldsymbol{\Lambda})$ derived from $(n 11)$ studies reported in the literature ${ }^{(5-7,15-18,52-55)}$ evaluating responses to calcium salts of CLA during early or established lactation.

well-established anti-lipogenic activity of this CLA isomer determined in other mammalian species ${ }^{(1,34)}$.

Experimental CLA treatments also resulted in a dose-dependent increase in milk fat trans-9, cis-11 CLA concentrations. Supplements were devoid of trans-9, cis-11 CLA, indicating that this isomer was derived from metabolism of CaCLA during transit through the gastrointestinal tract, absorption or in recipient tissues. Previous studies in lactating cows have also demonstrated that CaCLA supplements enrich trans-9, cis-11 CLA concentrations in milk fat ${ }^{(33)}$. Calcium salts of fatty acids have been developed to minimise the impact of supplemental lipid on ruminal digestion and microbial protein synthesis but do not afford complete protection from biohy-

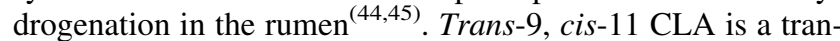
sitory intermediate of $18: 2 n-6$ metabolism in the rumen ${ }^{(33,46)}$. However, inclusion of CaCLA in the diet for both experiments decreased $18: 2 n-6$ intake, suggesting that trans-9, cis-11 CLA incorporated into milk originated from metabolism of fatty acids in the CaCLA supplement. Studies in the lactating cow have shown that trans-9, cis-11 CLA inhibits milk fat synthesis with an estimated efficacy of $50 \%$ compared with trans-10, cis-12 CLA $^{(35)}$. While significant, the small increases in milk fat trans-9, cis-11 CLA content to CaCLA treatments would tend to suggest a relatively minor contribution to the observed reductions in milk fat synthesis in the present study in goats.

The apparent discrepancy in milk fat responses to CaCLA determined in the present experiment compared with a lack of effect to intravenous ${ }^{(10)}$ or duodenal ${ }^{(11)}$ infusions of trans-10, cis-12 CLA reported in earlier studies in goats may have several causes. Both intravenous and abomasal infusions were established over a short interval $(2$ and $3 \mathrm{~d}$, respectively), while the incorporation of trans-10, cis-12 CLA in milk fat was much lower compared with the present data. It is possible that both the duration and amount of trans-10, cis-12 CLA infused were insufficient for the expression of anti-lipogenic activity in the caprine mammary gland. However, $72 \mathrm{~h}$ abomasal infusions have been shown to exert significant anti-lipogenic potential in the lactating bovine ${ }^{(2,3)}$, suggesting that differences in the amount of trans-10, cis-12 CLA infused or from the diet in rumen-protected form are the more probable explanation. Previous studies examining the effect of a lipid-encapsulated supplement of CLA containing trans-10, cis-12 CLA in lactating goats provided tentative evidence indicating that the amount of supplement required to inhibit milk fat synthesis is higher compared with the lactating cow when species comparisons are made on the basis of live weight ${ }^{(12,13)}$.

Irrespective of dietary fatty acid content, increases in trans-10, cis-12 CLA intake from CaCLA supplements resulted in curvilinear decreases in milk fat content (Fig. 2). Previous studies in lactating cows have established that the reduction in milk fat secretion to $\mathrm{CaCLA}^{(5-7)}$ or post-ruminal infusions of relative pure preparations of trans-10, cis-12 $\operatorname{CLA}^{(32,33)}$ also occurs in a dose-dependent non-linear manner. Such observations suggest that trans-10, cis-12 CLA acts via common mechanisms in ruminant species. The molecular mechanisms involved in the regulation of milk fat synthesis are not well defined, but studies in lactating cows have provided evidence that trans-10, cis-12 CLA decreases mammary tissue abundance of mRNA for lipogenic genes encoding for key enzymes involved in milk fat synthesis ${ }^{(33,34,47)}$. Due to a coordinated reduction in the expression of genes that encode for enzymes involved in de novo fatty acid synthesis, fatty acid uptake and transport, and triacylglycerol synthesis, it has been suggested that these changes are mediated via a pathway-specific central regulation of lipogenic gene expression with the SRBEP-1 transcription factor being identified as a possible candidate ${ }^{(34)}$. Studies in lactating $\operatorname{cows}^{(5-7,42)}$ and sheep ${ }^{(37,38)}$ have established that rumen-protected sources of trans-10, cis-12 CLA result in a reduction in the secretion of fatty acids derived from both de novo synthesis and circulating plasma lipids. By contrast, changes in milk fat composition in the lactating goat to CaCLA supplements determined in the present experiment revealed that the decrease in milk fat secretion was due to a reduction in fatty acids synthesised de novo, while the output of long-chain fatty acids was maintained, irrespective of dietary fatty acid intake. Differences in milk fatty acid composition point towards a lower inhibition of the uptake and incorporation of preformed fatty acids in response to trans-10, cis-12 CLA in the goat compared with the cow or sheep. 
The mean apparent efficiency of transfer of trans-10, cis-12 CLA from CaCLA supplements into caprine milk averaged $2.03 \%$, which is within the range of values $(1.9-7.4 \%)$ reported for studies in lactating cows ${ }^{(15)}$. A lack of difference between experiments suggests that the incorporation of trans-10, cis-12 CLA into caprine milk is independent of the supply of essentially saturated fatty acids at the mammary gland. Furthermore, comparable efficiencies of transfer determined in the goat and cow would tend to suggest that the digestion, absorption and partitioning of trans-10, cis-12 CLA supplied in rumen-protected form as calcium salts is comparable among ruminant species. Indirect comparisons of the relationship between reductions in milk fat content and yield with milk trans-10, cis-12 CLA enrichment (Fig. 3) determined in the present study for the goat with data from studies in lactating cows fed diets containing CaCLA supplements point towards species differences being related to reduced sensitivity of mammary lipogenesis to trans-10, cis-12 CLA rather than metabolism of CaCLA in the rumen. Post-ruminal infusion studies in lactating cows have established that trans-10, cis-12 CLA induces a maximal inhibition of milk fat synthesis of approximately $50 \%{ }^{(32-34)}$. Assuming that the incorporation in milk fat reflects the supply at the mammary gland, comparisons of milk trans-10, cis-12 CLA concentrations between ruminants fed CaCLA supplements causing a predicted $25 \%$ reduction in milk fat secretion (Fig. 3) suggest that the goat is between 4.1- and 4.8-fold less sensitive to the anti-lipogenic effects relative to the cow. Additional in vitro and in vivo studies examining the role of trans-10, cis-12 CLA on mRNA abundance on key lipogenic enzymes in caprine and bovine mammary tissue are required to identify the underlying causative mechanisms for these differences.

CaCLA supplements also induced decreases in the concentration ratios of product:substrate for $\Delta 9$-desaturase in milk fat. Milk fat cis-9-12:1:12:0, cis-9-14:1:14:0, cis-9-16:1:16:0 and cis-9-18:1:18:0 concentration ratios are known to be highly correlated with mRNA abundance and activity of $\Delta 9$-desaturase in the mammary gland of goats ${ }^{(47,48)}$. Previous studies have established that trans-10, cis-12 CLA decreases mRNA abundance for $\Delta 9$-desaturase in bovine mammary tissue $^{(49,50)}$. Measurements of milk fatty acid composition responses to CaCLA supplements also suggest that trans-10, cis-12 CLA down-regulates transcripts encoding for $\Delta 9$-desaturase in the caprine mammary gland. Earlier studies in the lactating goat reported that duodenal infusions of trans-10, cis-12 CLA decreased milk fat desaturase indices in the absence of an effect on milk fat synthesis ${ }^{(11)}$, consistent with the view that inhibition of $\Delta 9$-desaturase activity is not, in isolation, sufficient to induce a reduction in milk fat synthesis $^{(33)}$.

In conclusion, CaCLA supplements containing trans-10, cis-12 CLA reduced milk fat synthesis in lactating goats in a dose-dependent manner. Reductions in milk fatty acid output were due to reductions in the secretion of fatty acids synthesised de novo rather than fatty acids derived from circulating plasma lipids, leading to a shift in milk fat composition containing higher proportions of long-chain fatty acids. Differences in the extent of inhibition on milk fat content and yield between experiments indicated that anti-lipogenic activity in the goat is dependent on both the supply of trans-10, cis-12
CLA and long-chain fatty acids available to the mammary gland. Indirect comparisons of the relationship between reductions in milk fat secretion and milk fat trans-10, cis-12 CLA content in response to CaCLA supplements point towards the sensitivity of mammary lipogenesis to the inhibitory effects of trans-10, cis-12 CLA being several-fold lower in the goat compared with the cow.

\section{Acknowledgements}

The authors gratefully acknowledge and appreciate the staff of the 'Les Cèdres' Animal Nutrition and Metabolism Unit, André Combeau, Christophe Mathevon and Denis Roux, in particular, for the diligent care of experimental animals and the technical assistance of Pierre Capitan, Didier Bany, Cyril Labonne, Piia Kairenius and Vesa Toivonen. All authors have contributed to the preparation of the paper and agree with the submitted manuscript content. There are no conflicts of interest.

\section{References}

1. Bauman DE, Corl BA \& Peterson DG (2003) The biology of conjugated linoleic acid in ruminants. In Advances in Conjugated Linoleic Acid Research, vol. 2, pp. 146-173 [JL Sébédio, WW Christie and RO Adlof, editors]. Champaign, IL: AOCS Press.

2. Baumgard LH, Corl BA, Dwyer DA, Saeb $\varnothing$ A \& Bauman DE (2000) Identification of the conjugated linoleic acid isomer that inhibits milk fat synthesis. Am J Physiol 278, R179-R184.

3. Baumgard LH, Sangster JK \& Bauman DE (2001) Milk fat synthesis in dairy cows is progressively reduced by increasing supplemental amounts of trans-10, cis-12 conjugated linoleic acid (CLA). J Nutr 131, 1764-1769.

4. Peterson DG, Baumgard LH \& Bauman DE (2002) Short Communication: milk fat response to low doses of trans-10, cis-12 conjugated linoleic acid (CLA). J Dairy Sci 85, 1764-1766.

5. Giesy JG, McGuire MA, Shafii B \& Hanson TW (2002) Effect of dose of calcium salts of conjugated linoleic acid (CLA) on percentage and fatty acid content of milk fat in midlactation Holstein cows. J Dairy Sci 85, 2023-2029.

6. Moore CE, Hafliger HC, Mendivil OB, Sanders SR, Bauman DE \& Baumgard LH (2004) Increasing amounts of conjugated linoleic acid progressively reduces milk fat synthesis immediately postpartum. J Dairy Sci 87, 1886-1895.

7. Castañeda-Gutiérrez E, Overton TR, Butler WR \& Bauman DE (2005) Dietary supplements of two doses of calcium salts of conjugated linoleic acid during the transition period and early lactation. J Dairy Sci 88, 1078-1089.

8. Chilliard Y, Ferlay A, Rouel J \& Lamberet G (2003) A review of nutritional and physiological factors affecting goat milk lipid synthesis and lipolysis. J Dairy Sci 86, 1751-1770.

9. Chilliard Y, Glasser F, Ferlay A, Bernard L, Rouel J \& Doreau M (2007) Diet, rumen biohydrogenation, cow and goat milk fat nutritional quality. Eur J Lipid Sci Tech 109, 828-855.

10. Schmidely P \& Morand-Fehr P (2004) Effects of intravenous infusion of trans-10, cis-12 or cis-9, trans-11 conjugated linoleic acid (CLA) on milk fat synthesis and composition in dairy goats during mid-lactation. South Afr J Anim Sci 34, Suppl. 1, 195-197.

11. de Andrade PVD \& Schmidely P (2006) Effect of duodenal infusion of trans 10 , cis 12-CLA on milk performance and milk fatty acid profile in dairy goats fed high or low concentrate 
diet in combination with rolled canola seed. Reprod Nutr Dev 46, 31-48.

12. Erasmus LJ, Bester Z, Fourie T, Coertze RJ \& Hall L (2004) Effect of level of rumen protected CLA supplementation on milk yield and composition in Saanen goats. South Afr J Anim Sci 34, Suppl. 1, 42-45.

13. Rovai M, Lock A, Gipson T, Goetsch A \& Bauman D (2007) A conjugated linoleic acid (CLA) supplement containing trans-10, cis-12 CLA reduces milk fat synthesis in lactating goats. Italian J Anim Sci 6, Suppl. 1, 629-631.

14. Gulati SK, McGrath S, Wynn PC, Thomson PC \& Scott TW (2006) Rumen protected fat reverses the conjugated linoleic acid induced low milk fat content in dairy cows. Can J Anim Sci 86, 63-70.

15. de Veth MJ, Gulati SK, Luchini ND \& Bauman DE (2005) Comparison of calcium salts and formaldehyde-protected conjugated linoleic acid in inducing milk fat depression. $J$ Dairy Sci 88, $1685-1693$.

16. Bernal-Santos G, Perfield JW, Barbano DM, Bauman DE \& Overton TR (2003) Production responses of dairy cows to dietary supplementation with conjugated linoleic acid (CLA) during the transition period and early lactation. J Dairy Sci 86, 3218-3228.

17. Perfield JW, Bernal-Santos G, Overton TR \& Bauman DE (2002) Effects of dietary supplementation of rumen-protected conjugated linoleic acid in dairy cows during established lactation. J Dairy Sci 85, 2609-2617.

18. Piperova LS, Moallem U, Teter BB, Sampugna J, Yurawecz MP, Morehouse KM, Luchini D \& Erdman RA (2004) Changes in milk fat in response to dietary supplementation with calcium salts of trans-18:1 or conjugated linoleic fatty acids in lactating dairy cows. J Dairy Sci 87, 3836-3844.

19. Anonymous (1988) Arrêté du 19 avril 1988 fixant les conditions d'attribution de l'autorisation d'expérimenter. Journal Officiel de la République Française, 5608-5610.

20. Institut National de la Recherche Agronomique [Jarrige R, editor]. Ruminant Nutrition: Recommended Allowances and Feed Tables, pp. 389. Paris: INRA Publications.

21. Association of Official Analytical Chemists (1997) Official Methods of Analysis, $16^{\text {th }}$ Edition and $4^{\text {th }}$ revision. AOAC International: Gaithersburg, MD.

22. Folch J, Lees M, Sloane M \& Stanley GH (1957) A simple method for the isolation and purification of total lipids from animal tissues. J Biol Chem 226, 497-509.

23. Loor JJ, Ueda K, Ferlay A, Chilliard Y \& Doreau M (2004) Biohydrogenation duodenal flow, and intestinal digestibility of trans fatty acids and conjugated linoleic acids in response to dietary forage: concentrate ratio and linseed oil in dairy cows. J Dairy Sci 87, 2472-2485.

24. Christie WW (1982) A simple procedure of rapid transmethylation of glycerolipids and cholesteryl esters. J Lipid Res 23, $1072-1075$.

25. Roy A, Ferlay A, Shingfield KJ \& Chilliard Y (2006) Examination of the persistency of milk fatty acid composition responses to plant oils in cows fed different basal diets, with particular emphasis on trans-C18:1 fatty acids and isomers of conjugated linoleic acid. Anim Sci 82, 479-492.

26. Loor JJ, Ferlay A, Ollier A, Doreau M \& Chilliard Y (2005) Relationship among trans and conjugated fatty acids and bovine milk fat yield due to dietary concentrate and linseed oil. J Dairy Sci 88, 726-740.

27. Shingfield KJ, Reynolds CK, Hervás G, Griinari JM, Grandison AS \& Beever DE (2006) Examination of the persistency of milk fatty acid composition responses to fish oil and sunflower oil in the diet of dairy cows. J Dairy Sci 89, 714-732.

28. Shingfield KJ, Chilliard Y, Toivonen V, Kairenius P \& Givens DI (2008) Trans fatty acids and bioactive lipids in ruminant milk.
In Bioactive Components of Milk, Advances in Experimental Medicine and Biology 606, pp. 3-65 [Z Bösze, editor]. New York: Springer.

29. Shingfield KJ, Ahvenjärvi S, Toivonen V, Ärölä A, Nurmela KVV, Huhtanen P \& Griinari JM (2003) Effect of dietary fish oil on biohydrogenation of fatty acids and milk fatty acids content in cows. Anim Sci 77, 165-179.

30. Shingfield KJ, Reynolds CK, Lupoli B, Toivonen V, Yurawecz MP, Delmonte P, Griinari JM, Grandison AS \& Beever DE (2005) Effect of forage type and proportion of concentrate in the diet on milk fatty acid composition in cow given sunflower oil and fish oil. Anim Sci 80, 225-238.

31. Delmonte P, Kataok A, Corl BA, Bauman DE \& Yurawecz MP (2005) Relative retention order of all isomers of cis/trans conjugated linoleic acid FAME from the 6,8- to 13,15-positions using silver ion HPLC with two elution systems. Lipids 40, 509-514.

32. deVeth MJ, Griinari JM, Pfeiffer AM \& Bauman DE (2004) Effect of CLA on milk fat synthesis in dairy cows: comparison of inhibition by methyl esters and free fatty acids, and relationships among studies. Lipids 39, 365-372.

33. Shingfield KJ \& Griinari JM (2007) Role of biohydrogenation intermediates in milk fat depression. Eur J Lipid Sci Technol 109, 799-816.

34. Bauman DE, Perfield H II JW, Aarvatine KJ \& Baumgard LH (2008) Regulation of fat synthesis by CLA: lactation and the ruminant model. J Nutr 138, 403-409.

35. Perfield JW, Lock AL, Griinari JM, Sæbø A, Delmonte P, Dwyer DA \& Bauman DE (2007) Trans-9, cis-11 Conjugated linoleic acid (CLA) reduces milk fat synthesis in lactating dairy cows. J Dairy Sci 90, 2211-2218.

36. Sæbø A, Sæbø P, Griinari JM \& Shingfield KJ (2005) Effect of abomasal infusion of geometric isomers of 10,12 conjugated linoleic acid on milk fat synthesis in dairy cows. Lipids 40, 823-832.

37. Lock AL, Teles BM, Perfield JW, Bauman DE \& Sinclair LA (2006) A conjugated linoleic acid supplement containing trans-10, cis-12 reduces milk fat synthesis in lactating sheep. J Dairy Sci 89, 1525-1532.

38. Sinclair LA, Lock LA, Early R \& Bauman DE (2007) Effects of trans-10, cis-12 conjugated linoleic acid on ovine milk fat synthesis and cheese properties. J Dairy Sci 90, 3326-3335.

39. Gervais R, Spratt R, Leonard M \& Chouinard RY (2005) Lactation response of cows to different levels of ruminally inert conjugated linoleic acids under commercial conditions. Can J Anim Sci 85, 231-242.

40. Kay JK, Roche JR, Moore CE \& Baumgard LH (2006) Effects of dietary conjugated linoleic acid on production and metabolic parameters in transition dairy cows grazing fresh pasture. J Dairy Res 73, 367-377.

41. Loor JJ \& Herbein JH (2003) Reduced fatty acid synthesis and desaturation due to exogenous trans 10 , cis12-CLA in cows fed oleic or linoleic oil. J Dairy Sci 86, 1354-1369.

42. Bauman DE \& Griinari JM (2003) Nutritional regulation of milk fat synthesis. Ann Rev Nutr 23, 203-227.

43. Kadegowda AKG, Piperova LS \& Erdman RA (2008) Principal component and multivariate analysis of milk long-chain fatty acid composition during diet-induced milk fat depression. J Dairy Sci 91, 749-759.

44. Ferlay A, Chilliard Y \& Doreau M (1992) Effects of calcium salts differing in fatty acid composition on duodenal and milk fatty acid profiles in dairy cows. J Sci Food Agric 60, 31-37.

45. Jenkins TC \& Bridges WC (2007) Protection of fatty acids against ruminal biohydrogenation in cattle. Eur J Lipid Sci Technol 109, 778-789.

46. Wallace RJ, McKain N, Shingfield KJ \& Devillard E (2007) Isomers of conjugated linoleic acids are synthesized via different mechanisms in ruminal digesta and bacteria. J Lipid Res $\mathbf{4 8 ,}$ 2247-2254. 
47. Bernard L, Leroux C \& Chilliard Y (2008) Expression and nutritional regulation of lipogenic genes in the ruminant lactating mammary gland. In Bioactive Components of Milk, Advances in Experimental Medicine and Biology, vol. 606, pp. 67-108 [Z Bösze, editor]. New York: Springer.

48. Bernard L, Rouel J, Leroux C, Ferlay A, Faulconnier Y, Legrand P \& Chilliard Y (2005) Mammary lipid metabolism and milk fatty acid secretion in alpine goats fed vegetable lipids. J Dairy Sci 88, 1478-1489.

49. Baumgard LH, Matitashvili E, Corl BA, Dwyer DA \& Bauman DE (2002) Trans-10, cis-12 Conjugated linoleic acid decreases lipogenic rates and expression of genes involved in milk lipid synthesis in dairy cows. J Dairy Sci $\mathbf{8 5}, 2155-2163$.

50. Harvatine KJ \& Bauman DE (2006) SREBP1 and thyroid hormone responsive spot 14 (S14) are involved in the regulation of bovine mammary lipid synthesis during diet-induced milk fat depression and treatment with CLA. J Nutr 136, 2468-2474.

51. Sauvant D (1981) Alimentation énergétique des caprins. In Nutrition et Système d'alimentation de la Chèvre, Symposium international, Tours (France), 12-15 may 1981, pp. 55-79 [P Morand-Fehr, A Bourbouze and $\mathrm{M}$ de Simiane editors]. France: INRA-ITOVIC.

52. Selberg KT, Lowe AC, Staples CR, Luchini ND \& Badinga L (2004) Production and metabolic responses of periparturient Holstein cows to dietary conjugated linoleic acid and transoctadecenoic acids. J Dairy Sci 87, 158-168.

53. Moore CE, Kay JK, Collier RJ, VanBaale MJ \& Baumgard LH (2005) Effect of supplemental conjugated linoleic acids on heatstressed Brown Swiss and Holstein cows. J Dairy Sci 88, $1732-1740$.

54. Odens LJ, Burgos R, Innocenti M, VanBaale MJ \& Baumgard LH (2007) Effects of varying doses of supplemental conjugated linoleic acid on production and energetic variables during the transition period. J Dairy Sci 90, 293-305.

55. Huang Y, Schoonmaker JP, Bradford BJ \& Beitz DC (2008) Response of milk fatty acid composition to dietary supplementation of soy oil, conjugated linoleic acid, or both. J Dairy Sci 91, 260-270. 